\title{
Constitutive Kit activity triggers B cell acute lymphoblastic leukemia-like disease in mice
}

DOI:

10.1016/j.exphem.2016.09.005

\section{Document Version}

Accepted author manuscript

Link to publication record in Manchester Research Explorer

\section{Citation for published version (APA):}

Weidemann, R. R., Behrendt, R., Schoedel, K. B., Müller, W., Roers, A., \& Gerbaulet, A. (2016). Constitutive Kit activity triggers $\mathrm{B}$ cell acute lymphoblastic leukemia-like disease in mice. Experimental Hematology. https://doi.org/10.1016/j.exphem.2016.09.005

\section{Published in:}

Experimental Hematology

\section{Citing this paper}

Please note that where the full-text provided on Manchester Research Explorer is the Author Accepted Manuscript or Proof version this may differ from the final Published version. If citing, it is advised that you check and use the publisher's definitive version.

\section{General rights}

Copyright and moral rights for the publications made accessible in the Research Explorer are retained by the authors and/or other copyright owners and it is a condition of accessing publications that users recognise and abide by the legal requirements associated with these rights.

\section{Takedown policy}

If you believe that this document breaches copyright please refer to the University of Manchester's Takedown Procedures [http://man.ac.uk/04Y6Bo] or contact uml.scholarlycommunications@manchester.ac.uk providing relevant details, so we can investigate your claim.

\section{OPEN ACCESS}




\section{Accepted Manuscript}

Constitutive Kit activity triggers B cell acute lymphoblastic leukemia-like disease in mice

Robin R. Weidemann, Rayk Behrendt, Kristina B. Schoedel, Werner Müller, Axel Roers, Alexander Gerbaulet

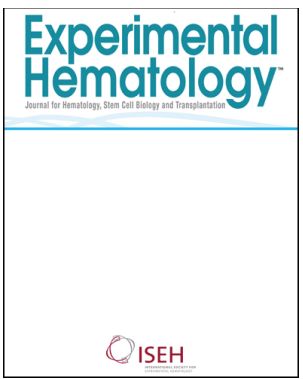

PII: S0301-472X(16)30615-4

DOI: 10.1016/j.exphem.2016.09.005

Reference: $\quad$ EXPHEM 3462

To appear in: Experimental Hematology

Received Date: 11 March 2016

Revised Date: 17 August 2016

Accepted Date: 14 September 2016

Please cite this article as: Weidemann RR, Behrendt R, Schoedel KB, Müller W, Roers A, Gerbaulet A, Constitutive Kit activity triggers B cell acute lymphoblastic leukemia-like disease in mice, Experimental Hematology (2016), doi: 10.1016/j.exphem.2016.09.005.

This is a PDF file of an unedited manuscript that has been accepted for publication. As a service to our customers we are providing this early version of the manuscript. The manuscript will undergo copyediting, typesetting, and review of the resulting proof before it is published in its final form. Please note that during the production process errors may be discovered which could affect the content, and all legal disclaimers that apply to the journal pertain. 
Constitutive Kit activity triggers B cell acute lymphoblastic leukemia-like disease in mice

Robin R. Weidemann ${ }^{1}$, Rayk Behrendt ${ }^{1}$, Kristina B. Schoedel ${ }^{1}$, Werner Müller ${ }^{2}$, Axel

Roers $^{1}$ and Alexander Gerbaulet ${ }^{1}$

${ }^{1}$ Institute for Immunology, Medical Faculty "Carl Gustav Carus", TU Dresden,

Dresden, Germany

${ }^{2}$ Faculty of Life Sciences, University of Manchester, Manchester, United Kingdom

Running title: $\mathrm{B}-\mathrm{ALL}$ in $\mathrm{Kit}^{\mathrm{D} 814 \mathrm{~V}}$ transgenic mice

Correspondence: Alexander Gerbaulet, Institute for Immunology, Medical Faculty

TU Dresden, Fetscherstrasse 74, D-01307 Dresden, Germany, +49 3514586503

Email: alexander.gerbaulet@tu-dresden.de

Category: Malignant Hematopoiesis

Word count: 3740 words (Introduction, Material \& methods, Results and Discussion), Highlights:

- $\mathrm{Kit}^{\mathrm{D} 814 \mathrm{~V}}$ mutation causes acute lymphoblastic leukemia-like disease in mice

- Leukemic cells originate from Igu-rearranged pro-B cells

- Leukemogenesis does not require pre-B cell receptor expression

Graphical abstract: please see supplementary figure S4 


\section{Abstract}

Acute lymphoblastic leukemia (ALL) is the most common childhood malignancy and is of pro- or pre-B cell origin in most cases. The receptor tyrosine kinase KIT is expressed by hematopoietic stem and precursor cells. Gain-of-function mutations of KIT cause systemic mastocytosis, which is characterized by abnormal accumulations of mast cells. We previously reported a mouse model of mastocytosis based on conditional expression of a constitutively active Kit protein. Half of these animals developed leukemic disease of B lineage origin. Herein, we report that this condition bears striking similarities to human B-ALL. The immuno-phenotype of the leukemic cells was compatible with a pro-B cell origin, as was the finding of immunoglobulin heavy chain gene rearrangements in all cases, whereas light chain loci were mostly not rearranged. Leukemogenesis was independent of pre-B cell receptor expression. Primary leukemic cells and permanent cell lines derived from these were serially transplantable and rapidly killed the recipients. In few animals, the leukemia was of T cell origin with abnormal CD4/8 double positive $\mathrm{T}$ cell precursors dominating in the circulation. In summary, we report a novel ALL mouse model that may prove useful for in vivo drug testing and identification of novel oncogenic mutations and principles.

\section{Introduction}

The bone marrow continuously generates enormous numbers of B cells, each equipped with a unique surface immunoglobulin (Ig) antigen receptor. This is possible by an ordered sequence of somatic recombination events that result in random rearrangements of the $\lg$ heavy chain $(\mathrm{lgH})$ and light chain $(\lg \mathrm{L})$ loci. This process of $\mathrm{V}(\mathrm{D}) \mathrm{J}$ recombination commences in pro-B cells with $\mathrm{D}$ to $\mathrm{J}$ rearrangements of the $\mathrm{IgH}$ loci [1]. A productive $\mathrm{IgH}$ rearrangement results in surface 
expression of the pre-B cell receptor (BCR) complex composed of a functional heavy chain and a surrogate light chain [2]. Antigen-independent, "tonic" signaling by this complex triggers a number of rapid cell divisions but subsequently also provides antiproliferative and maturation signals [3]. $\mathrm{V}(\mathrm{D}) \mathrm{J}$ recombination of $\mathrm{T}$ cell receptor loci and $\mathrm{T}$ cell development in the thymus follow similar principles [4].

Malignant growth of a precursor B cell clone causes B cell acute lymphoblastic leukemia (B-ALL), the most common malignant disease in childhood [5]. In $20 \%$ of ALL cases, the malignant clone originates from precursor $T$ cells. B-ALL is genetically heterogeneous and can be grouped according to the presence of several characteristic oncogenic mutations or translocations [6]. A common theme, however, is that B-ALL clones are arrested at the pre-B cell checkpoint, hi-jack pre-BCR signaling for their survival but at the same time evade the anti-proliferative and differentiation cues from physiological pre-BCR signaling [7]. In a fraction of B-ALL patients, the malignant clone depends on tonic signaling from a functional pre-BCR for its survival .

The tyrosine kinase KIT, the receptor for the hematopoietic growth factor stem cell factor (SCF) is expressed by hematopoietic stem cells as well as all progenitor cells [8]. While more mature cells of all lineages gradually shut down KIT expression, mast cells remain dependent on KIT signaling for their entire life-span. KIT activation triggers several signaling pathways, including phosphoinositol 3-kinases (PI3K), Src family kinases and the mitogen-activated-protein-kinase (MAPK), janus kinase/signal transducers and activators of transcription (JAK/STAT) and phospholipase C and D signaling [9]. Gain-of-function mutations of KIT that result in constitutive, ligandindependent signaling cause the human disease mastocytosis [10]. This condition is characterized by accumulations of abnormal numbers of mast cells. A significant fraction of systemic mastocytosis patients (up to $30 \%$ ) present with associated clonal 
hematological non-mast cell lineage disease (AHNMD), typically myeloproliferative, myelodysplastic syndromes or myeloid leukemias [10].

We recently generated a transgenic mouse model for mastocytosis [11]. These animals conditionally express the $\mathrm{Kit}^{\mathrm{D} 814 \mathrm{~V}}$ mutation, which is the murine homolog of the most common mastocytosis-associated mutation in humans, $K I T^{D 816 \mathrm{~V}}$. Transgenic expression of the mutant protein is controlled by the Kit promoter. Effects of the constitutively active Kit transgene were dependent on developmental stage and cell type. Widespread expression in the embryo resulted in lethal erythroid hyperproliferation, while induction of transgene expression in adult mice led to massive mastocytosis. This latter condition was associated with an additional hematopoietic neoplasm in about half of the animals, which rapidly succumbed to this disease. These mice featured lymphadenopathy, an abnormal population of CD $19^{+} B 220^{+}$cells in the blood, and infiltration of various organs by blastic B cells. These findings suggested that uncontrolled Kit activity causes B cell leukemia in mice. Herein, we pinpoint the origin of this B cell malignancy.

\section{Materials and Methods}

\section{Mice}

Kit ${ }^{\text {D814Vflox }}$ Mx1-Cre (Tg(Kit*D814V)1Roer) [11], $\lg H^{\mu M T}$ [12], B6.CD45.1 (B6.SJLPtprc $^{a}$ Pepc ${ }^{b} /$ BoyJ), and CD19-Cre [13] mice were housed at the Experimental Center, TU Dresden in a specific pathogen free barrier facility. All strains were on the C57BL/6 background and animal experiments were in accordance with institutional guidelines and approved by the relevant authority, the Landesdirektion Dresden (Ref. No. 24-9168.24-1/2012-4 and 24-9168.11-1/2012-39). 
In some animals, Mx1-Cre was induced by a total of three i.p. injections of $250 \mu \mathrm{g}$ poly-inosinic:poly-cytidilic acid (pl:pC, Invivogen, Toulouse, France) every second day. Uninduced Kit ${ }^{\text {D814Vflox }}$ Mx1-Cre mice developed similar phenotypes due to background recombination of Mx1-Cre [11].

\section{Southern blotting}

Genomic DNA was isolated from enlarged lymph nodes of leukemic mice, $10 \mu \mathrm{g}$ DNA was digested over night with $30 \mathrm{u}$ of either EcoRI or HindlII restriction endonuclease (both from Fermentas), separated by agarose gel electrophoresis and immobilized on a positively charged nylon membrane (Roche). Radioactive probes were synthesized using the Ladderman labeling kit (TaKaRa) from PCR products generated with primer pairs specific for either the IgH locus (5'-AAGAGGACCTCTCCAGTTTCGGCT-3' and $5^{\prime}$-GCCTGCAAAAGTCCAGCTTTCA-3') or the $\lg \kappa$ locus $\left(5^{\prime}\right.$ 'CTGGGTCTGACTGCAGGTAGCGT-3' and 5'- AGTGGTCCACGCGGAGCAAGG$\left.3^{\prime}\right)$. Probes were hybridized over night in Ultrahyb buffer (Ambion) at $42^{\circ} \mathrm{C}$ and bands were visualized on a phosphoimager (Molecular Dynamics / GE Healthcare). Ig $\mu$ or Igא genomic DNA served as germline control and was isolated from BAC clones RP23-270B12 and RP23-435I4 (ImaGenes, Berlin, Germany), respectively.

\section{Cell preparation}

Bone marrow (BM) was isolated from femora by flushing with PBS $/ 5 \%$ FCS. Erythrocytes were lysed by brief incubation with hypotonic $\mathrm{NH}_{4} \mathrm{Cl}$ buffer. Single cell suspensions were generated by gently mashing spleen, thymus or lymph node tissue through a $70 \mu \mathrm{m}$ sieve. Spleen cell suspensions were subjected to erythrocyte lysis. Peripheral blood (PB) was obtained by retro-orbital bleeding and collected in heparinized glass capillaries and red blood cells were lysed. 
Cell lines were generated by cultivating BM single cell suspensions from leukemic animals in RPMI1640 (Gibco) supplemented with 10\% FCS, 2 mM L-Alanyl-LGlutamin, Penicillin/Streptomycin (all from Biochrom, Berlin, Germany), $50 \mu \mathrm{M} 2-$ Mercaptoethanol (Sigma-Aldrich) at $37^{\circ} \mathrm{C}$ and $5 \% \mathrm{CO}_{2}$. To assess proliferation, triplicates of 40,000 cells in $200 \mu \mathrm{l}$ medium were seeded into 96 well plates and cell numbers were determined at indicated time points using a MACSquant flow cytometer (Miltenyi Biotec).

\section{Flow cytometry}

Cells were incubated with monoclonal antibodies (see supporting information table 1 for detailed overview) for 30 minutes in PBS/5\% FCS, washed twice and analyzed on FACS LSRII or FACS Calibur (Becton Dickinson). Data analysis was performed using FlowJo V9 software (Treestar).

For transplantation of purified cell populations, cells were sorted on a BD FACS ARIAII, mixed with 200,000 BM "carrier" cells of recipient origin and retro-orbitally i.v. injected.

For analysis of intracellular phosphoprotein expression, cells were fixed using IC fixation buffer (eBioscience) and methanol followed by incubation with phosphospecific antibodies (see supplementary table 1) and analysis on a BD FACS Calibur flow cytometer.

\section{Statistics}

Kaplan-Meier survival curves were plotted using Prism 5 (Graphpad). Significance between survival curves was calculated using the Log-rank test (Fig 3A, 4A, 7C and S3D). Two-sided Student's t-test was used for group comparison (Fig 6C and S1B ). Time course data (Fig 6B and S3C) were analyzed with repeated measure one-way 
ANOVA and Tukey's multiple comparisons test. Dose response data (Fig 6D, S2B and S3F) were analyzed with one-way ANOVA and Bonferroni correction for multiple comparisons. The frequency and confidence interval of leukemia initiating cells was calculated using ELDA software [14].

Significant results are indicated by: ${ }^{*} p=0.01-0.05,{ }^{* *} p=0.001-0.01$, and ${ }^{* * *} p<0.001$; not significant results by: ns. Means \pm standard deviation (SD) are shown throughout all figures.

\section{Results}

Immuno-phenotype of neoplastic B cells from leukemic Kit ${ }^{D 14 V}$ transgenic mice resembles pro-B cells.

The conditional expression of the constitutively active $K i t^{D 814 V}$ mutation in our mouse model is based on controlled excision of a loxP-flanked stop element by Cremediated recombination leaving the mutant Kit gene under the control of the endogenous Kit promoter contained in the BAC transgene [11]. Excision of the loxPflanked stop by Cre expressed from the type I IFN-inducible Mx1-Cre transgene resulted in mastocytosis in $100 \%$ of $\mathrm{Kit}^{\mathrm{D} 814 \mathrm{VIflox}+} \mathrm{Mx} 1-\mathrm{Cre}^{+}$animals. About half of these animals developed an additional $B$ lineage leukemia until the age of six months that was frequently lethal within few days after first clinical manifestation [11]. Flow cytometric analysis of peripheral blood (PB) and spleen from diseased Kit ${ }^{\text {D814Vflox+ }}$ $\mathrm{Mx} 1-\mathrm{Cre}^{+}$mice revealed an abnormal population of B220 intermediate (B220 $\left.{ }^{\text {int }}\right)$ BP-1 high $\left(\mathrm{BP}-1^{\text {hi }}\right)$ cells (Fig $\left.1 \mathrm{~A}\right)$, which were negative for surface IgM (Fig S1A). Many animals featured macroscopically enlarged lymph nodes, which represented an essentially pure population of the $\mathrm{B} 220^{\mathrm{int}} \mathrm{BP}-1^{\text {hi }}$ cells (Fig $1 \mathrm{~A}$ ). Analysis of bone marrow (BM) cells demonstrated almost complete replacement of hematopoiesis by 


\section{ACCEPTED MANUSCRIPT}

$\mathrm{B} 220^{+} \mathrm{BP}-1^{+}$cells (Fig S1B). BM B220 cells from leukemic mice were negative for $\lg \mathrm{M}$ and $\operatorname{lgD}$ and uniformly over-expressed CD19 and BP-1, while CD34, CD135, CD21/35 and CD79b were not detected and only few cells expressed CD25 and Sca1 (Fig 1B and S1C). B220, CD24, CD43, CD93 and CD127 expression levels of the abnormal cells were similar to those of control precursor B cells (B220 ${ }^{\text {int }}$ CD $43^{\text {hi }}$ ) [15]. Taken together, the malignant $\mathrm{B} 220^{+}$cells immuno-phenotypically resembled Hardy fraction B or C pro-B cells of the "Philadelphia nomenclature" [1], a population that overlaps with pre-B-I cells of the "Basel nomenclature" [16] (see Fig S4 for an overview).

\section{Neoplastic B lineage clones carry rearranged IgH but mostly germ line configured Ig $\mathrm{loci}$.}

In order to further narrow down the differentiation state of the neoplasia, we analyzed the configuration of the $\operatorname{lgH}$ and $\lg \kappa$ loci in DNA isolated from enlarged lymph nodes of leukemic animals. Southern blot analysis revealed one or two non-germline bands in all cases (Fig 2A), providing formal proof that the $\mathrm{B} 220^{\text {int }} \mathrm{BP}-1^{\text {hi }}$ cells represent a clonal population of $\mathrm{D}-\mathrm{J}_{\mathrm{H}}$ rearranged $\mathrm{B}$ lineage cells (the probe used did not

discriminate between $\mathrm{D}-\mathrm{J}_{\mathrm{H}}$ and $\mathrm{V}-\mathrm{D} \mathrm{J}_{\mathrm{H}}$ rearrangements). Germline bands occurred in most samples and were either caused by mono-allelic recombination or stroma cells. In contrast, the Igא locus was germline-configured in eight of nine cases analyzed (Fig 2B). This clearly demonstrates that most leukemias originated from cells that had undergone heavy chain, but not light chain rearrangement. 


\section{Malignant transformation of precursor B cells in Kit ${ }^{D 14 V}$ transgenic mice is independent of pre-B cell receptor signals.}

Analysis of Ig gene rearrangements and immuno-phenotype of neoplastic cells revealed their similarity to pro-B cells. During normal B cell development, surface expression of a functional pre-BCR triggers a proliferative burst of pre-B cells [17, 18], but also mediates anti-proliferative and maturation signals [7]. We hypothesized that pre-BCR expression critically impacts malignant transformation of $\mathrm{Kit}^{\mathrm{D} 814 \mathrm{~V}} \mathrm{~B}$ cell progenitors, and crossed Kit ${ }^{D 814 V \text { flox }} M \times 1-C r e$ mice to the $\lg H^{\mu M T}$ strain, that is incapable of expressing a functional pre-BCR [12]. In $\lg H^{\mu M T}$ animals, B cell development is blocked in Hardy fraction C $[15,19]$, which overlaps with pre-B-I cells [20]. The incidence of lethal B lineage neoplasia was not significantly altered in $\mathrm{Kit}^{\mathrm{D}^{814 \mathrm{~V} f l o x+} \mathrm{Mx} 1-\mathrm{Cre}^{+}} \lg \mathrm{H}^{\mu M T / \mu M T}$ mice compared to $\mathrm{lgH}$ proficient littermate controls (Fig 3A). Flow cytometric analysis of diseased animals confirmed the presence of $\mathrm{B} 220^{\text {int }} \mathrm{BP} 1^{\text {hi }}$ cells in $\mathrm{Kit}^{\mathrm{D814V \text {flox }}+} \mathrm{Mx} 1-\mathrm{Cre}^{+} \mathrm{Ig} \mathrm{H}^{\mu M T / \mu M T}$ animals (Fig 3B). Complete absence of surface Ig on all $\mathrm{BM} \mathrm{B} 220^{+}$B cells confirmed the blockade in pro-B cell fraction $\mathrm{C}$ ensuing from the $\lg \mathrm{H}^{\mu M T}$ mutation. The frequent development of leukemia in mice lacking a functional pre-BCR proves the irrelevance of pre-BCR surface expression for leukemogenesis in $K_{i t}^{D 814 V}$ transgenic mice. Thus, the transforming event must have occurred in or upstream of Hardy fraction $C$ pro-B cells.

\section{Selective expression of $\mathrm{Kit}^{\mathrm{D} 814 \mathrm{~V}}$ in $\mathrm{CD} 19^{+} \mathrm{B}$ cell precursors is sufficient to trigger malignant transformation.}

In order to restrict $\mathrm{Kit}^{\mathrm{D} 814 \mathrm{~V}}$ expression to B-lineage committed progenitors, we crossed the Kit ${ }^{D 814 \text { flox }}$ allele to $C D 19-C r e$ mice [13]. In the latter, Cre-mediated recombination initiates after pre-pro-B cells (Hardy fraction A [15]) and is efficient in fraction B pro-B cells [21-23]. The majority of Kit D814Vflox+ $^{\mathrm{C} D 19-\mathrm{Cre}^{+}}$mice (9 of 12 


\section{ACCEPTED MANUSCRIPT}

mice, Fig 4A) died spontaneously or was sacrificed for end stage disease between 9 to 17 weeks of age. All animals analyzed by flow cytometry (7/9) exhibited strong infiltration of the BM with $B 220^{+} B P-1^{\text {hi }}$ cells (Fig 4B). Similar to the disease in $\mathrm{Kit}^{\mathrm{D814Vflox+}} \mathrm{Mx1-Cre^{+ }}$ mice, the leukemic cells uniformly expressed CD24, CD43, CD93, CD117 and CD127 (not shown). Three double transgenic mice were sacrificed at an age ranging from 22 to 36 weeks without macroscopic signs of illness and were devoid of $B 220^{+} B P-1^{\text {hi }}$ BM infiltration. The development of precursor B cell leukemia in mice with CD19-specific Kit ${ }^{\mathrm{D} 814 \mathrm{~V}}$ activation further demonstrated that $\mathrm{Kit}^{\mathrm{D} 814 \mathrm{~V}_{-}}$ expression starting from Hardy fraction B pro-B cells is sufficient to trigger the disease.

\section{High frequency of leukemia initiating cells.}

In order to determine the frequency of leukemia initiating cells [24] within the malignant clone, we purified $B 220^{\text {int }} \mathrm{BP}-1^{\text {hi }} \mathrm{CD} 117^{+}$cells from a diseased Kit ${ }^{\text {D14VFlox }}$ Mx1-Cre ${ }^{+}$donor by flow cytometry and injected cell numbers ranging from $10^{1}$ to $5 \mathrm{x}$ $10^{4}$ cells into un-conditioned congenic B6.CD45.1 recipients (Fig 5A). We monitored recipient PB for appearance of donor-derived $\left(C D 45.2^{+}\right) B 220^{\text {int }} B P-1^{\text {hi }}$ cells (Fig 5B) and found dose dependent engraftment and expansion of donor cells. All mice developed end stage disease between 19 to 34 days after transfer. Only two of the three recipients, which received ten leukemic precursor-B cells survived without detectable engraftment of donor cells in PB and BM and did not develop leukemia within 137 days after transfer. The frequency of leukemia initiating cells was determined to be about 1 in 20 leukemic cells (Fig 5C). 


\section{Derivation of pro-B cell lines.}

We cultivated leukemic cells from the BM of the diseased Kit ${ }^{D 14 V \text { flox+ }}$ Mx1-Cre ${ }^{+}$ animal represented in Fig S2A. The cultivated cells maintained B220 and BP-1 expression (Fig 6A) and rapidly proliferated in serum-containing media (Fig 6B). We investigated the malignant potential of the cell line (termed "RW7938") by i.v. injection of $10^{6}$ cells into congenic B6.CD45.1 mice ( $n=3$, Fig 6C). All recipients appeared moribund 14 days after transfer and were sacrificed. We determined the frequency of donor-derived CD $45.2^{+} \mathrm{BP}-1^{\text {hi }}$ cells among BM cells (Fig 6C) and found strong BM infiltration and expansion of donor pro-B cells. We similarly cultivated a cell line ("AG11232") from a diseased $\mathrm{Kit}^{\mathrm{D} 814 \mathrm{Vflox}+} \mathrm{CD} 19-\mathrm{Cre}^{+}$animal that rapidly grew in culture and was transplantable (Fig S3)

Next, we compared the phosphorylation of intracellular signaling proteins of Kit ${ }^{\mathrm{D} 814 \mathrm{~V}}$ pro-B cell lines to primary lymphocytes and found constitutive phosphorylation of ERK1/2, mTOR, STAT3/5 and AKT pathways (Fig 6E, S2C and S3E). This constitutive activation could be blocked by nanomolar concentrations of the tyrosine kinase inhibitors PKC412 and Dasatinib (Fig 6D, S2B and S3F), which have been shown to target the $\mathrm{Kit}^{\mathrm{D} 814 \mathrm{~V}}$ mutation $[25,26]$. Imatinib did not block phosphorylation of $\mathrm{Kit}^{\mathrm{D} 814 \mathrm{~V}}$ target proteins and inhibited cell growth only at high micromolar concentrations (Fig S2B,C and S3E,F). The decreased growth rate of Rapamycintreated pro-B cell lines showed that constitutive activation of the mTOR signaling pathway contributes to aberrant growth of these cell lines.

\section{Rare occurrence of pre-T cell leukemia in Kit ${ }^{\text {D814Vflox }} M \times 1-C r e$ mice.}

Less than $5 \%$ of $\mathrm{Kit}^{\mathrm{D814 \textrm {V } f l o x +}} \mathrm{M} \times 1-\mathrm{Cre}^{+}$mice developed large thymi (Fig 7A). These animals featured an abnormal population of CD4/8 double positive cells in PB and spleen (Fig 7B). Thymus analysis revealed a massive increase of CD4/CD8 double 
positive (DP) thymocytes at the expense of single positive cells. The DP thymocytes showed strong upregulation of CD25 and moderate upregulation of CD117 (Fig 7B) and CD44 (not shown) in comparison to control DP thymocytes. The CD4/8 double negative (DN) thymocytes displayed an aberrant $\mathrm{CD}_{4} 4^{+}$and $\mathrm{CD} 25^{\mathrm{lo}}$ phenotype. Upon transfer of different numbers of total thymic cells from a diseased Kit ${ }^{\text {D814Vflox+ }}$ $\mathrm{M} \times 1-\mathrm{Cre}^{+}$animal, congenic recipient mice $\mathrm{In}$ recipients that received $1 \times 10^{6}$-donor thymocytes, high numbers of CD4/8 DP cells of donor origin appeared in PB 13 days after transfer. These mice succumbed within two months after transplantation and reproduced the original lethal disease (Fig 7C). Thymocytes from a diseased recipient animal were serially transplanted and killed secondary recipients within few weeks.

\section{Discussion}

In the present work, we have identified Hardy fraction B/C pro-B cells [15] which overlap with pre-B-I cells [2] as the origin of the B cell precursor malignancy (see Fig S4 for an overview), which spontaneously developed in transgenic mice expressing a mutant, constitutively active Kit receptor $\left(\mathrm{Kit}^{\mathrm{D814VFlox+}} \mathrm{Mx1-Cre^{+ }}\right.$ transgenic mice). We showed that the transformed cells transferred the disease to unconditioned recipients which rapidly succumbed to leukemia. In addition, we characterized the $\mathrm{T}$ cell precursor leukemia that a minority of mice developed.

Flow cytometric analysis revealed that the leukemic cells of all animals analyzed featured a remarkably uniform immuno-phenotype that suggested a pre-B-I cell [16] or pro-B cell origin [1]. The cells expressed common pro-B lymphocyte markers including CD24, CD43, CD93, CD117, CD127 and BP-1 [15, 22, 27], whereas surface Ig expression as a hallmark of the B cell stage was absent [28]. CD19 was consistently over-expressed and may contribute to malignant transformation as loss 
of CD19 was shown to attenuate disease progression in the $E \mu$-myc mouse model [29]. The finding of rearranged $\mathrm{IgH}$, but germ line configured $\lg \kappa$ loci, provided additional evidence for clonal outgrowth of pro-B cells, which usually harbor $D_{H}$ to $J_{H}$ but not $\lg \kappa$ rearrangements. The rearranged $\mathrm{IgH}$ loci could allow for surface expression of a functional pre-BCR complex, which, in normal B cell development, triggers expansion of clones, which successfully recombined $\lg \mathrm{H}$. Pre-BCR signals also mediate tumor suppressor effects [7]. In a minority of human pre-B-ALL cases, the leukemic cells rely on tonic pre-BCR signaling [30]. However, disease incidence and phenotype were not altered in $\mathrm{Kit}^{\mathrm{D814Vflox+}} \mathrm{Mx1-Cre}{ }^{+}$mice on an IgH-deficient background $\left(\lg H^{\mu M T / \mu M T}\right)$, demonstrating that functional pre-BCR expression was not a prerequisite for malignant transformation or progression in our model. This finding also underpinned that the cellular origin was within or upstream of fraction $\mathrm{C}$ pro-B cells, since the $\lg H^{\mu M T / \mu M T}$ allele blocks B cell development in Hardy fraction C [19]. Occurrence of leukemia in mice with a blockade in pro-B cells also proves that dedifferentiation and reacquisition of a pro-B cell phenotype by more mature B cells through oncogenic transformation [31] does not occur in Kit ${ }^{D 814 V}$ transgenic mice.

In a complementary experiment, in which $\mathrm{Kit}^{\mathrm{D} 814 \mathrm{~V}}$ expression was induced by $\mathrm{Cre}$ recombinase expressed from the CD19-Cre knock-in allele [13], we found a high incidence of $B$ cell precursor leukemia. This observation demonstrated that the transformation within or after Hardy fraction B is sufficient to cause the disease, because fraction A cells are CD19-negative and CD19-Cre starts to recombine in fraction $B$ pro-B cells [21-23]. The ubiquitous activation of $\mathrm{Kit}^{\mathrm{D} 814 \mathrm{~V}}$ in pro-B cells by CD19-Cre may explain the earlier onset and higher entrance of the disease in $\mathrm{Kit}^{\mathrm{D814V+}} \mathrm{CD} 19-\mathrm{Cre}^{+}$animals as compared to un-induced $\mathrm{Kit}^{\mathrm{D814V \text {flox+}}} \mathrm{Mx1-Cr \textrm {C } ^ { + }}$ animals with sporadic Cre expression [32] and mosaic activation of $\mathrm{Kit}^{\mathrm{D} 814 \mathrm{~V}}$. Taken together, several lines of evidence prove that the malignant transformation usually 
occurred in fraction B or C pro-B cells. Nevertheless, we cannot exclude the possibility of transformation upstream of fraction $\mathrm{B}$ and $\mathrm{C}$ in $\mathrm{Kit}^{\mathrm{D} 814 \mathrm{Vflox}{ }^{+}} \mathrm{Mx1-Cre}{ }^{+}$ mice as hematopoietic stem and progenitor cells already harbor the activated $K i t^{D 814 V}$ transgene.

Most childhood and adult B-ALL fall into the subgroup "common ALL" (BII according to the EGIL immuno-phenotypic classification [33]) in which the leukemic cells express CD10 compatible with a pre-B-I cell [20] origin of the disease in human. A direct comparison between immuno-phenotypes of human and murine B lineage cells is difficult as CD10 and CD34 are not expressed during murine B cell development [34] and B220, CD25, CD117 and BP-1 are not expressed by human B cell progenitors [20]. However, close to $100 \%$ of common B-ALL clones carry rearranged IgH loci but only a fraction additionally harbors IgL rearrangements [35]. Thus, the neoplastic B cells of our Kit ${ }^{D 14 V}$ transgenic mice resemble human B-Il ALL blasts.

Over the last two decades, the cancer stem cell concept emerged, which proposes a hierarchical organization of neoplasms equivalent to cellular homeostasis in normal tissues [24]. Rare self-renewing cancer stem cells give rise to more differentiated neoplastic cells with a finite life span, which account for most of the tumor mass, a concept that was also shown to be relevant in leukemic diseases, in particular $\mathrm{AML}$ [36]. In contrast, close to $100 \%$ of blastic B cells in human B-ALL seem to be capable of initiating the leukemia upon xenotransplantation $[37,38]$. The leukemia of $K_{i t}^{D 814 V}$ transgenic mice was successfully transplanted by transfer of low numbers of cells, suggesting that most or all leukemic cells have the capacity to initiate the disease. Therefore, a hierarchical organization of the malignant clone and the existence of a special subset of leukemia initiating cells seem unlikely [39].

The leukemic B cells vigorously proliferated and infiltrated numerous organs upon transfer into unconditioned recipients. The transplanted cells homed efficiently to the 


\section{ACCEPTED MANUSCRIPT}

BM and rapidly displaced normal hematopoiesis. Leukemic cells readily proliferated in vitro showing that they were independent of the BM microenvironment, in contrast to primary precursor B cells which require complex culture conditions including feeder cells and cytokines.

$\mathrm{Kit}^{\mathrm{D} 814 \mathrm{~V}}$ rendered the animals susceptible for development of precursor $\mathrm{B}$ cell leukemia, but was not sufficient to induce the disease on its own, given the incomplete penetrance of the leukemic phenotype. We can only speculate about additional mutations that synergize with $\mathrm{Kit}^{\mathrm{D} 814 \mathrm{~V}}$ and are required to transform $\mathrm{B}$ - or T-cell precursors. $\mathrm{V}(\mathrm{D}) \mathrm{J}$ recombination is a well-established cause of transient genomic instability and frequently leads to oncogenic translocations [40].

Deregulated tyrosine kinase signaling was detected in human $\mathrm{T}$ cell acute lymphoblastic leukemia, but activating KIT mutations were not reported [41]. KIT is frequently expressed in early $T$ cell precursor $A L L$, but this expression may reflect the immature cell origin rather than being linked to malignant transformation [42]. Kit ${ }^{D 814 V}$ transgenic mice rarely developed a $\mathrm{T}$ cell ALL-like disease which may stem either from uncommitted lymphoid progenitors or from cells that were already committed to T cell development.

In man, the $K I T^{D 816 V}$ mutation causes systemic mastocytosis, which is accompanied by additional hematological non-mast cell lineage diseases in some cases [10]. These additional hematological diseases are usually of myeloid origin. In such cases, the neoplastic mast cells and myeloid cells shared a common clonal origin and both harbored the activating KIT mutation [43]. There are infrequent reports of mastocytosis with additional lymphocytic neoplasia [44, 45]. However, the activating KIT mutation was usually not detected in cells of the accompanying lymphocytic disease [44]. In the few cases, in which $K I T^{D 816 V}$ was detected in B lymphocytes, the B cell compartment remained oligoclonal and did not exhibit signs of malignant 


\section{ACCEPTED MANUSCRIPT}

transformation [46]. Our mice and a different $K i t^{D 814 V+}$ mouse model [47] developed B lineage neoplasia with high frequency. This discrepancy between murine models and humans expressing activating KIT mutations might be explained by different signaling activity of murine versus human KIT receptor [48].

However, there are important similarities of the B cell leukemia in our animals to human B-II ALL, including immuno-phenotype, partial rearrangement of lg loci, developmental arrest close to the pre-BCR checkpoint and an incidence peak at young age. Moreover, deregulated signaling via the PI3K/AKT/mTOR [49], MAPK [50], and JAK/STAT [51] pathways is crucial for development of ALL. All of the latter pathways are activated by the $\mathrm{Kit}^{\mathrm{D814V}}$ mutation [52] and contributed in $\mathrm{Kit}^{\mathrm{D} 814 \mathrm{~V}}$ pro-B cell lines to growth factor independent proliferation as demonstrated by treatment with PKC412 and Dasatinib. Moreover, Philadelphia chromosome-like (Ph-like) ALL, a subtype with unfavorable prognosis exhibits defined genomic alterations, which in most cases lead to deregulated kinase activity [53]. Therefore, deregulated tyrosine kinase activity in Kit ${ }^{D 814 V+}$ B-ALL may model an important aspect of human Ph-like ALL with activation of similar downstream pathways.

In another mouse model of human leukemia, the E $\mu$-TCL1 transgenic mouse model for chronic lymphocytic leukemia (CLL) [54], the precipitating mutation is not characteristic of the majority of human CLL. However, since the signaling pathways activated and additional oncogenic hits are very similar to the human disease, the model has proven its value in CLL research [55].

Collectively, our Kit ${ }^{D 814 V}$ triggered B-ALL mouse model might prove valuable for identification of additional oncogenic mutations and mechanisms, which may contribute to leukemogenesis in humans. Our model could be useful to test antileukemic strategies including targeting aberrant molecular pathways as well as immmuno-therapeutic approaches. 


\section{Acknowledgments}

The authors thank Tobias Häring, Livia Schulze and Christina Hiller for expert technical assistance. This work was supported by the Fritz Thyssen foundation (research grant no. 10.05.2.171 and 10.07.2.142) to A.R., the Kind Philipp Stiftung für Leukämieforschung to R.W. and a TU Dresden MeDDrive 2012 grant to A.G. The authors thank Ralf Küppers and Martin Bornhäuser for critical reading of the manuscript and Justus Duyster for scientific discussion.

\section{Author contribution:}

A.G. and R.R.W. performed experiments; A.G., R.R.W., R.B. and K.B.S. analyzed data, W.M. advised the study, A.G. and A.R. designed the research study and wrote the paper.

\section{Conflict of interest disclosure}

The authors declare no conflict of interests.

\section{References}

[1] Hardy RR, Hayakawa K. B cell development pathways. Annu Rev Immunol. 2001;19:595-621.

[2] Rolink A, Melchers F. Molecular and cellular origins of B lymphocyte diversity. Cell. 1991;66:1081-1094.

[3] Rickert RC. New insights into pre-BCR and BCR signalling with relevance to $B$ cell malignancies. Nat Rev Immunol. 2013;13:578-591.

[4] Rothenberg EV, Taghon T. Molecular genetics of T cell development. Annu Rev Immunol. 2005;23:601-649.

[5] Pui C-H, Robison LL, Look AT. Acute lymphoblastic leukaemia. Lancet. 2008;371:1030-1043.

[6] Inaba H, Greaves M, Mullighan CG. Acute lymphoblastic leukaemia. Lancet. 2013;381:1943-1955.

[7] Eswaran J, Sinclair P, Heidenreich O, et al. The pre-B-cell receptor checkpoint in acute lymphoblastic leukaemia. Leukemia. 2015;29:1623-1631.

[8] Broudy VC. Stem cell factor and hematopoiesis. Blood. 1997;90:1345-1364.

[9] Lennartsson J, Rönnstrand L. Stem Cell Factor Receptor/c-Kit: From Basic Science to Clinical Implications. Physiol Rev. 2012;92:1619-1649. 
[10] Valent P, Akin C, Escribano L, et al. Standards and standardization in mastocytosis: Consensus Statements on Diagnostics, Treatment Recommendations and Response Criteria. Eur J Clin Invest. 2007;37:435-453.

[11] Gerbaulet A, Wickenhauser C, Scholten J, et al. Mast cell hyperplasia, B-cell malignancy, and intestinal inflammation in mice with conditional expression of a constitutively active kit. Blood. 2011;117:2012-2021.

[12] Kitamura D, Roes J, Kuhn R, Rajewsky K. A B cell-deficient mouse by targeted disruption of the membrane exon of the immunoglobulin [mu] chain gene. Nature. 1991;350:423-426.

[13] Rickert RC, Roes J, Rajewsky K. B lymphocyte-specific, Cre-mediated mutagenesis in mice. Nucleic Acids Res. 1997;25:1317-1318.

[14] Hu Y, Smyth GK. ELDA: extreme limiting dilution analysis for comparing depleted and enriched populations in stem cell and other assays. J Immunol Methods. 2009;347:70-78.

[15] Hardy RR, Carmack CE, Shinton SA, Kemp JD, Hayakawa K. Resolution and characterization of pro-B and pre-pro-B cell stages in normal mouse bone marrow. J Exp Med. 1991;173:1213-1225.

[16] Rolink AG, ten Boekel E, Yamagami T, Ceredig R, Andersson J, Melchers F. $B$ cell development in the mouse from early progenitors to mature $B$ cells. Immunol Lett. 1999;68:89-93.

[17] Karasuyama H, Rolink A, Shinkal Y, Young F, Alt FW, Melchers F. The expression of $V$ pre-B/ $\lambda 5$ surrogate light chain in early bone marrow precursor $B$ cells of normal and B cell-deficient mutant mice. Cell. 1994;77:133-143.

[18] Hess J, Werner A, Wirth T, Melchers F, Jäck H-M, Winkler TH. Induction of pre-B cell proliferation after de novo synthesis of the pre-B cell receptor. Proc Natl Acad Sci U S A. 2001;98:1745-1750.

[19] Ehlich A, Schaal S, Gu H, Kitamura D, Müller W, Rajewsky K. Immunoglobulin heavy and light chain genes rearrange independently at early stages of B cell development. Cell. 1993;72:695-704.

[20] Ghia P, ten Boekel E, Rolink AG, Melchers F. B-cell development: a comparison between mouse and man. Immunol Today. 1998;19:480-485.

[21] Opferman JT, Letai A, Beard C, Sorcinelli MD, Ong CC, Korsmeyer SJ. Development and maintenance of $B$ and T lymphocytes requires antiapoptotic MCL1. Nature. 2003;426:671-676.

[22] Rumfelt LL, Zhou Y, Rowley BM, Shinton SA, Hardy RR. Lineage specification and plasticity in CD19- early B cell precursors. J Exp Med. 2006;203:675-687.

[23] Rolink A, ten Boekel E, Melchers F, Fearon DT, Krop I, Andersson J. A subpopulation of B220+ cells in murine bone marrow does not express CD19 and contains natural killer cell progenitors. J Exp Med. 1996;183:187-194.

[24] Clarke MF, Dick JE, Dirks PB, et al. Cancer Stem Cells - Perspectives on Current Status and Future Directions: AACR Workshop on Cancer Stem Cells. Cancer Res. 2006;66:9339-9344.

[25] Gotlib J, Berubé C, Growney JD, et al. Activity of the tyrosine kinase inhibitor PKC412 in a patient with mast cell leukemia with the D816V KIT mutation. Blood. 2005;106:2865-2870.

[26] Shah NP, Lee FY, Luo R, Jiang Y, Donker M, Akin C. Dasatinib (BMS-354825) inhibits KITD816V, an imatinib-resistant activating mutation that triggers neoplastic growth in most patients with systemic mastocytosis. Blood. 2006;108:286-291.

[27] Rolink A, Grawunder U, Winkler TH, Karasuyama H, Melchers F. IL-2 receptor a chain (CD25, TAC) expression defines a crucial stage in pre-B cell development. International Immunology. 1994;6:1257-1264. 
[28] Rajewsky K. Clonal selection and learning in the antibody system. Nature. 1996;381:751-758.

[29] Poe JC, Minard-Colin V, Kountikov El, Haas KM, Tedder TF. A c-Myc and Surface CD19 Signaling Amplification Loop Promotes B Cell Lymphoma Development and Progression in Mice. The Journal of Immunology. 2012;189:23182325.

[30] Geng H, Hurtz C, Lenz Kyle B, et al. Self-Enforcing Feedback Activation between BCL6 and Pre-B Cell Receptor Signaling Defines a Distinct Subtype of Acute Lymphoblastic Leukemia. Cancer Cell. 2015;27:409-425.

[31] Cobaleda C, Jochum W, Busslinger M. Conversion of mature B cells into T cells by dedifferentiation to uncommitted progenitors. Nature. 2007;449:473-477.

[32] Kühn R, Schwenk F, Aguet M, Rajewsky K. Inducible gene targeting in mice. Science. 1995;269:1427-1429.

[33] Bene MC, Castoldi G, Knapp W, et al. Proposals for the immunological classification of acute leukemias. European Group for the Immunological Characterization of Leukemias (EGIL). Leukemia. 1995;9:1783-1786.

[34] Kalled SL, Siva N, Stein H, Reinherz EL. The distribution of CD10 (NEP 24.11, CALLA) in humans and mice is similar in non-lymphoid organs but differs within the hematopoietic system: absence on murine $\mathrm{T}$ and $\mathrm{B}$ lymphoid progenitors. European Journal of Immunology. 1995;25:677-687.

[35] van der Burg M, Barendregt BH, Szczepanski T, van Wering ER, Langerak $A W$, van Dongen JJ. Immunoglobulin light chain gene rearrangements display hierarchy in absence of selection for functionality in precursor-B-ALL. Leukemia. 2002;16:1448-1453.

[36] Bonnet D, Dick JE. Human acute myeloid leukemia is organized as a hierarchy that originates from a primitive hematopoietic cell. Nat Med. 1997;3:730737.

[37] le Viseur C, Hotfilder M, Bomken S, et al. In Childhood Acute Lymphoblastic Leukemia, Blasts at Different Stages of Immunophenotypic Maturation Have Stem Cell Properties. Cancer Cell. 2008;14:47-58.

[38] Rehe K, Wilson K, Bomken S, et al. Acute B lymphoblastic leukaemiapropagating cells are present at high frequency in diverse lymphoblast populations. EMBO Mol Med. 2013;5:38-51.

[39] Kelly PN, Dakic A, Adams JM, Nutt SL, Strasser A. Tumor growth need not be driven by rare cancer stem cells. Science. 2007;317:337-337.

[40] Küppers R, Dalla-Favera R. Mechanisms of chromosomal translocations in B cell lymphomas. Oncogene. 2001;20:5580-5594.

[41] Van Vlierberghe $P$, Ferrando A. The molecular basis of $T$ cell acute lymphoblastic leukemia. J Clin Invest. 2012;122:3398-3406.

[42] Coustan-Smith E, Mullighan CG, Onciu M, et al. Early T-cell precursor leukaemia: a subtype of very high-risk acute lymphoblastic leukaemia. Lancet Oncol. 2009;10:147-156.

[43] Sotlar K, Colak S, Bache A, et al. Variable presence of KITD816V in clonal haematological non-mast cell lineage diseases associated with systemic mastocytosis (SM-AHNMD). J Pathol. 2010;220:586-595.

[44] Kim Y, Weiss LM, Chen Y-Y, Pullarkat V. Distinct clonal origins of systemic mastocytosis and associated B-cell lymphoma. Leuk Res. 2007;31:1749-1754.

[45] Tzankov A, Sotlar K, Muhlematter D, et al. Systemic mastocytosis with associated myeloproliferative disease and precursor B lymphoblastic leukaemia with $\mathrm{t}(13 ; 13)(\mathrm{q12} ; \mathrm{q22})$ involving FLT3. J Clin Pathol. 2008;61:958-961. 
[46] Taylor ML, Sehgal D, Raffeld M, et al. Demonstration That Mast Cells, T Cells, and B Cells Bearing the Activating Kit Mutation D816V Occur in Clusters within the Marrow of Patients with Mastocytosis. J Mol Diagn. 2004;6:335-342.

[47] Kitayama H, Tsujimura T, Matsumura I, et al. Neoplastic transformation of normal hematopoietic cells by constitutively activating mutations of c-kit receptor tyrosine kinase. Blood. 1996;88:995-1004.

[48] Xiang Z, Kreisel F, Cain J, Colson A, Tomasson MH. Neoplasia Driven by Mutant c-KIT Is Mediated by Intracellular, Not Plasma Membrane, Receptor Signaling. Mol Cell Biol. 2007;27:267-282.

[49] Kharas MG, Janes MR, Scarfone VM, et al. Ablation of PI3K blocks BCR-ABL leukemogenesis in mice, and a dual PI3K/mTOR inhibitor prevents expansion of human BCR-ABL(+) leukemia cells. J Clin Invest. 2008;118:3038-3050.

[50] Knight T, Irving JAE. Ras/Raf/MEK/ERK pathway activation in childhood acute lymphoblastic leukemia and its therapeutic targeting. Front Oncol. 2014;4.

[51] Mullighan CG, Zhang J, Harvey RC, et al. JAK mutations in high-risk childhood acute lymphoblastic leukemia. Proc Natl Acad Sci U S A. 2009;106:9414-9418.

[52] Ma P, Mali RS, Martin H, Ramdas B, Sims E, Kapur R. Role of intracellular tyrosines in activating KIT-induced myeloproliferative disease. Leukemia. 2012;26:1499-1506.

[53] Roberts KG, Li Y, Payne-Turner D, et al. Targetable Kinase-Activating Lesions in Ph-like Acute Lymphoblastic Leukemia. New England Journal of Medicine. 2014;371:1005-1015.

[54] Bichi R, Shinton SA, Martin ES, et al. Human chronic lymphocytic leukemia modeled in mouse by targeted TCL1 expression. Proc Natl Acad Sci U S A. 2002;99:6955-6960.

[55] Simonetti G, Bertilaccio MTS, Ghia P, Klein U. Mouse models in the study of chronic lymphocytic leukemia pathogenesis and therapy. Blood. 2014;124:10101019. 


\section{Figure legends}

\section{Figure 1}

Immuno-phenotype of neoplastic B cells from leukemic Kit ${ }^{D 814 V}$ transgenic mice resembles pro-B cells.

A) Peripheral blood (PB), spleen and lymph node cells of leukemic Kit ${ }^{\text {814Vflox }}$ Mx1Cre mice were analyzed for expression of B220 and BP-1. B) Whole bone marrow cells (WBMC) were analyzed by flow cytometry for expression of B-lymphocyte markers. Upper left histogram shows gating of $\mathrm{B}^{2} 20^{+}$bone marrow cells (diseased $K_{i t}^{\text {D814Vflox+ }}$ Mx1-Cre ${ }^{+}$animal, red; healthy Mx1-Cre ${ }^{-}$or Kit ${ }^{\text {D814Vflox- }}$ littermate controls, blue; unstained cells as negative control, grey; 13 animals analyzed, one representative result is shown). $B 220^{+}$WBMC were analyzed for expression of the following markers (representative results are shown, number of replicates analyzed is given): CD19 ( $n=6), \operatorname{CD} 93(n=3), \operatorname{CD} 34(n=4), \operatorname{CD} 24(n=7), \operatorname{slgM}(n=4), \operatorname{slg} D(n=3)$, $\operatorname{CD} 25(n=5), \operatorname{CD} 117(n=13) \operatorname{BP} 1(n=11), \operatorname{CD} 43(n=9)$, and CD127 $(n=3)$.

\section{Figure 2}

Neoplastic B lineage clones carry rearranged IgH but mostly germ line configured Igk loci.

A) Southern blot strategy (left scheme) for detection of $\operatorname{lgH} \mathrm{D}$ to $\mathrm{J}$ rearrangements. Germline configuration of the murine $\lg \mu$ locus is shown (not drawn to scale; $E$, EcoRI restriction site). An example of a $D_{H}$ to $J_{H}$ rearrangement is depicted in the lower part. Southern blot analysis (right) of genomic DNA isolated from lymph nodes of individual $\mathrm{Kit}^{\mathrm{D814Vflox+}} \mathrm{Mx1-Cre}{ }^{+}$mice $(\# 1-\# 9)$ detected at least a single $\mathrm{D}_{H}$ to $\mathrm{J}_{H}$ rearrangement in all samples. Two parts of the same blot are shown. Horizontal line 


\section{ACCEPTED MANUSCRIPT}

indicates approximate position of the $6.2 \mathrm{~kb}$ germline fragment (germline control DNA isolated from BAC clone).

B Southern blot strategy (left scheme) for detection of $\lg \kappa \mathrm{V}$ to $\mathrm{J}$ rearrangements. Germline configuration of the murine $\lg \kappa$ locus is shown (not drawn to scale; $H$, HindIII restriction site). An example of a $\mathrm{V} \kappa$ to $\mathrm{J} \kappa$ rearrangement is depicted in the lower part. Southern blot analysis (right) of genomic DNA isolated from lymph nodes of individual mice (\#1 - \#9, same animals as in $A$ ) demonstrated absence of to $V_{K}$ to $\mathrm{J}_{\mathrm{K}}$ rearrangements in all samples except for animal \#1. Two parts of the same blot are shown. Horizontal line indicates approximate position of the $2.7 \mathrm{~kb}$ germline fragment (germline control DNA isolated from BAC clone).

\section{Figure 3}

Malignant transformation of precursor B cells in Kit ${ }^{D 14 V}$ transgenic mice is independent of pre-B cell receptor signals.

A) Survival of IgH deficient $K i t^{D 814 V f l o x+} M x 1-C r e^{+} \lg H^{\mu M T / \mu M T}$ (" $\mu \mathrm{MT} / \mu \mathrm{MT}$ ", $\mathrm{n=19}$ ), IgH competent $K_{i t}{ }^{D 814 V f l o x+} M x 1-C^{+} e^{+} \lg H^{\mu M T / w t},(" \mu M T / w t ", n=22)$ and Mx1-Cre $e^{-}$or $\mathrm{Kit}^{\text {D814Vflox- }}\left(\lg \mathrm{H}^{\mu \mathrm{MT} / \mu \mathrm{MT}}\right.$ or $\lg \mathrm{H}^{\mu \mathrm{MT} / \mathrm{wt}}$, "ctrl", $\left.\mathrm{n=51}\right)$ littermate animals was monitored (asterisks indicate significant difference in survival between control group and $\mu \mathrm{MT} / \mu \mathrm{MT}$ or $\mu \mathrm{MT} /$ wt group).

B) Leukemic Kit ${ }^{D 814 V f l o x+} M x 1-C r e^{+}$animals $\left(\lg H^{\mu M T / \mu M T}, n=7\right.$, or $\left.\lg H^{\mu M T / w t}, n=4\right)$ and single transgenic controls were sacrificed and analyzed by flow cytometry for presence of malignant $\mathrm{B} 220^{\text {int }} \mathrm{BP}-1^{\text {hi }} \mathrm{BM}$ cells (upper panel, representative contour plots). B220 ${ }^{+}$BM cells were stained for surface $\operatorname{lgM}$ and $\operatorname{lgD}(\mathrm{n}=3-4$ / genotype, lower panel). 


\section{Figure 4}

Selective expression of $\mathrm{KIT}^{\mathrm{D} 814 \mathrm{~V}}$ in $\mathrm{CD}^{+}{ }^{+} \mathrm{B}$ cell precursors is sufficient to trigger malignant transformation.

A) Survival of Kit ${ }^{\text {D814Vflox+ }} C D 19-\mathrm{Cre}^{+}$mice $(\mathrm{n}=12)$ and littermate controls ("ctrl", lacking either $C D 19-C r e$ or $K_{i t}^{D 814 V \text { flox }}$ or both transgenes, $\mathrm{n}=29$ ) was monitored. $\mathbf{B}$ ) 7 of 9 mice that succumbed were analyzed by flow cytometry and all showed $\mathrm{B} 220^{+} \mathrm{BP}-1^{\text {hi }} \mathrm{BM}$ infiltrates. One representative result is shown.

\section{Figure 5}

\section{High frequency of leukemia initiating cells.}

A) Schematic representation of transplantation of different numbers of FACS purified B220 int $\mathrm{BP}-1^{\text {hi }} \mathrm{CD} 117^{+}$leukemic cells from a diseased $\mathrm{Kit}^{\mathrm{D} 814 \mathrm{Vflox}+} \mathrm{Mx1-Cr \textrm {C } ^ { + }}$ mouse into congenic B6.CD45.1 wildtype recipients.

B) PB of recipients was screened for donor-derived leukemic pro-B cells and the frequency of $C D 45.2^{+} B P-1^{\text {hi }}$ cells among PB leukocytes $(\mathrm{PBL})$ was determined. Individual recipients are shown. Crosses indicate that the animals were sacrificed because of high leukemic burden.

C) Table gives an overview of donor cell doses and the fraction of recipients succumbing to leukemia after transplantation. Limiting dilution analysis (right) estimated a frequency of leukemia initiating cells of 1 in 22 (dashed lines show $95 \%$ confidence interval, only the data from transfer of $10^{1}$ and $10^{2}$ donor cells was plotted).

\section{Figure 6}

Derivation of precursor B cell line. 


\section{ACCEPTED MANUSCRIPT}

A) BM cells were cultivated in RPMI1640 10\% FCS medium for more than 10 passages. Flow cytometry revealed a homogenous population of $B 220^{+} B P 1^{\text {hi }}$ cells (blue, WBMC of healthy negative control mouse; red, cell line RW7938). B) Expansion of RW7938 cells in vitro. The number of viable cells was determined at indicated time points. The experiment (representative of 4 independent experiments) was performed in three replicates (means \pm SD are shown). C) $10^{6}$ RW7938 cells were i.v. injected into unconditioned congenic B6.CD45.1 recipients ( $n=3$, left panel). Recipients had to be sacrificed 15 days after transfer for obvious end-stage disease and frequency of donor-derived $\left(\mathrm{CD} 45.2^{+}\right)$BP $-1^{\text {hi }}$ cells (middle panel) among WBMCs were determined (right panel, controls were not injected with donor cells). D) Triplicates of RW7938 cells were cultivated in presence of increasing PKC412 (LClabs, Woburn, MA) concentrations. Cell counts were determined after 48h (means \pm SD are shown, significance between RW7938 cells treated with increasing doses and RW7938 cells treated with the lowest dose of PKC412 was calculated). E) RW7938 cells were incubated for $2 \mathrm{~h}$ in the presence of $1 \mu \mathrm{M}$ PKC412 (black histogram) or left untreated (solid histogram). Cells were fixed and stained with phosphoprotein-specific antibodies and analyzed by flow cytometry. Freshly isolated splenocytes from B6 wt mice (dashed histogram) served as a control for expression of phosphoproteins by primary lymphocytes.

\section{Figure 7}

\section{Rare occurrence of pre-T cell leukemia in Kit ${ }^{\text {814Vflox }} M \times 1-C r e$ mice.}

A) Below $5 \%$ of $\mathrm{Kit}^{\mathrm{D814V \text {flox+}}} \mathrm{Mx1-Cre^{+ }}$ animals sacrificed for obvious end stage disease featured grossly enlarged thymi. B) Flow cytometric analysis of peripheral blood, spleen and thymus of a diseased $\mathrm{Kit}^{\mathrm{D814Vflox+}} \mathrm{Mx1-Cre}{ }^{+}$animal (lower row) and a single transgenic littermate control (upper row) animal. Note the abnormal CD4/8 


\section{ACCEPTED MANUSCRIPT}

double positive $\mathrm{T}$ cell population appearing in blood and spleen. The CD4/8 double negative (DN) fraction was further characterized by staining for CD44 and CD25. Histograms (far right) show expression of CD117 and CD25 on transformed CD4/8 double positive (DP) thymocytes. C) CD4/CD8 immuno-phenotype (left dot plots) of thymocytes from diseased $\mathrm{Kit}^{\mathrm{D814VFlox+}} \mathrm{Mx1-Cre}{ }^{+}$animal (lower plot) and littermate control (upper plot) which were subsequently transplanted i.v. into unconditioned B6.CD45.1 recipients ( $n=3 /$ cell dose) at numbers ranging from $10^{3}$ to $10^{6}$. Donorderived CD4/8 DP thymocytes appeared in the PB of recipients 68 days after transplantation of $10^{6}$ thymocytes from the leukemic animal (lower right dot plot). Mice which received $10^{6}$ thymocytes succumbed within 56 - 68 days (upper right). Transplantation of $10^{6}$ thymocytes from a primary recipient that received $10^{6}$ primary cells into secondary B6.CD45.1 recipient mice resulted in rapid development of end stage leukemic disease (lower right). 


\section{ACCEPTED MANUSCRIPT}

A

PB

Spleen
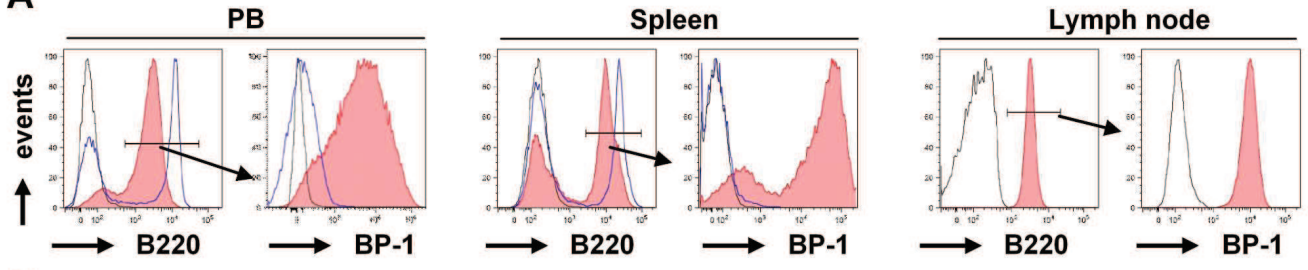

B

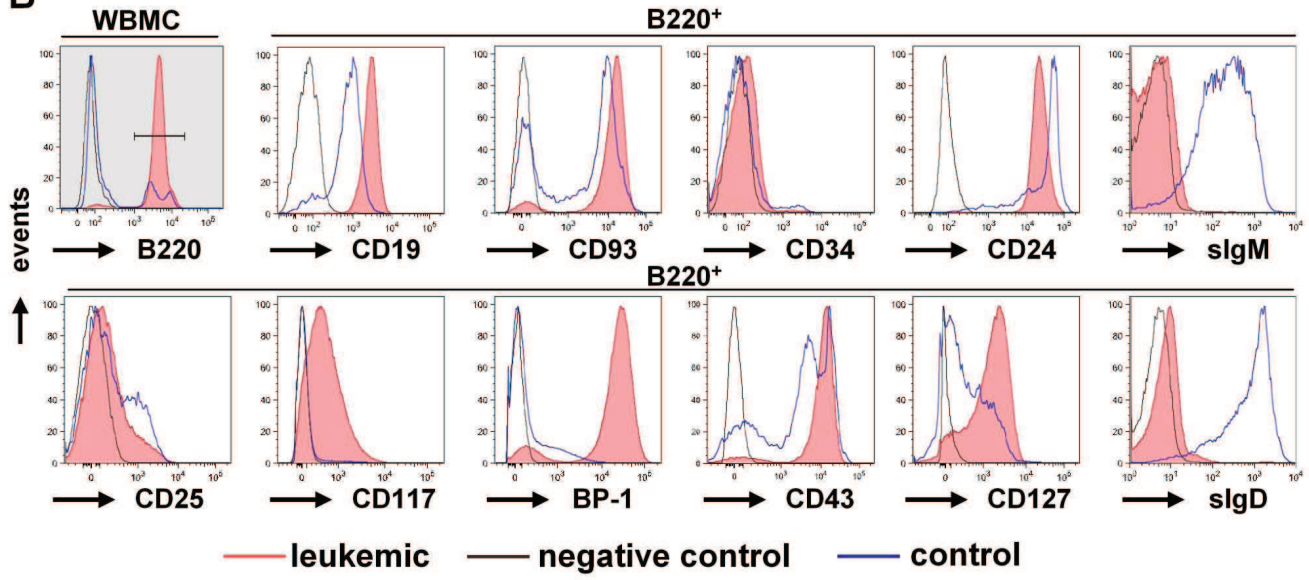

Figure 1 

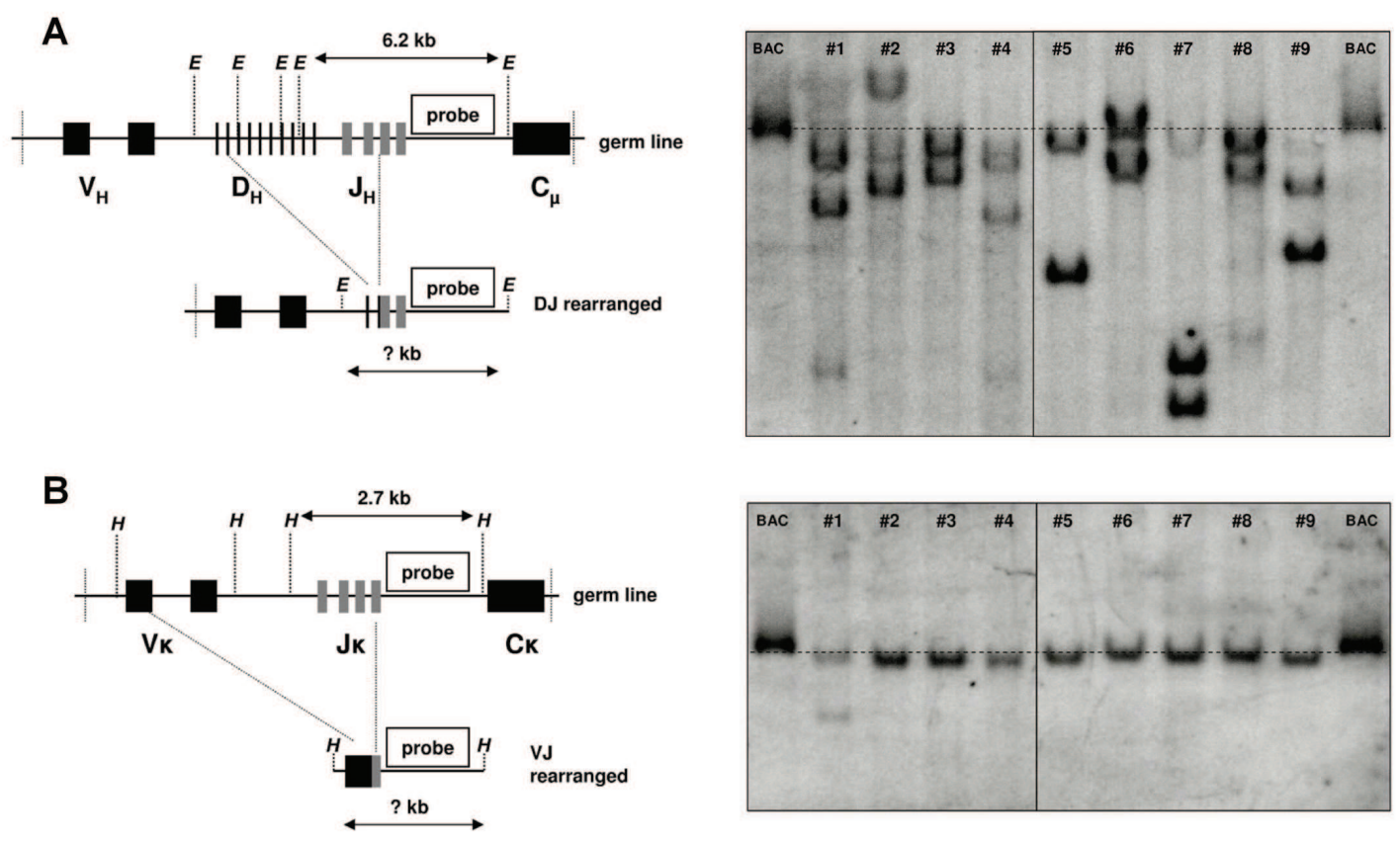

Figure 2 
A

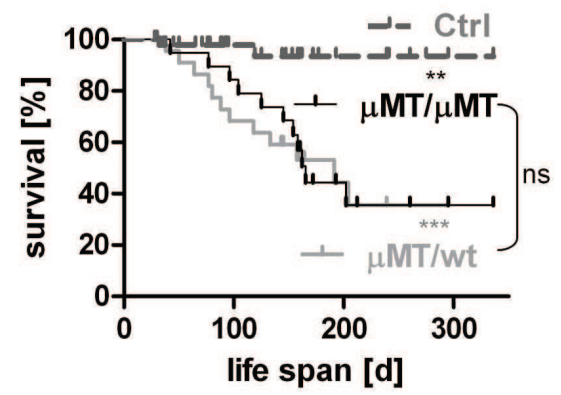

Figure 3
B

B Control

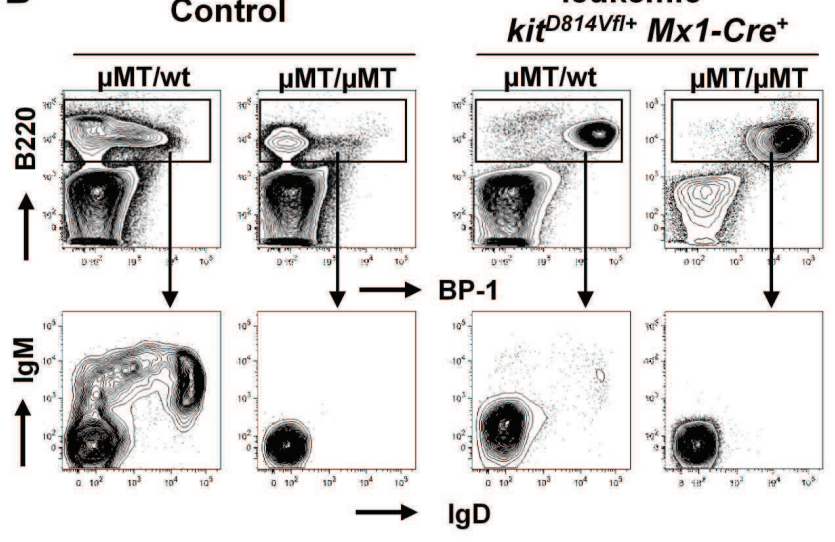




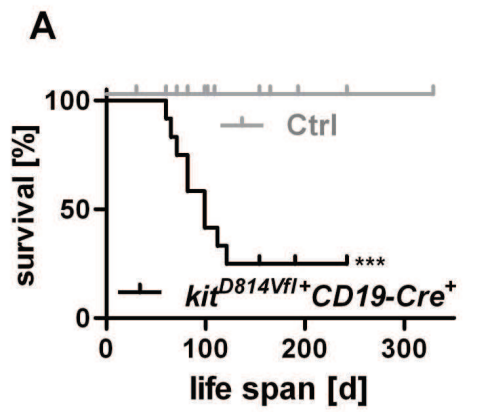

Figure 4

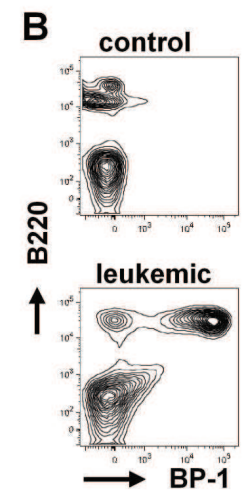


A

$10^{1}-5 \times 10^{4}$ B220 $^{\text {int }} B P-1^{\text {hi }}$

CD117 ${ }^{+}$purified donor cells

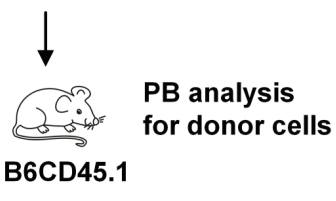

C

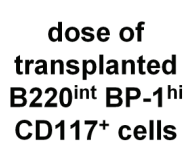

$10^{1}$

$10^{2}$

$10^{3}$

$5 \times 10^{4}$ fraction of responding recipients
$1 / 3$
$3 / 3$
$3 / 3$
$2 / 2$

B
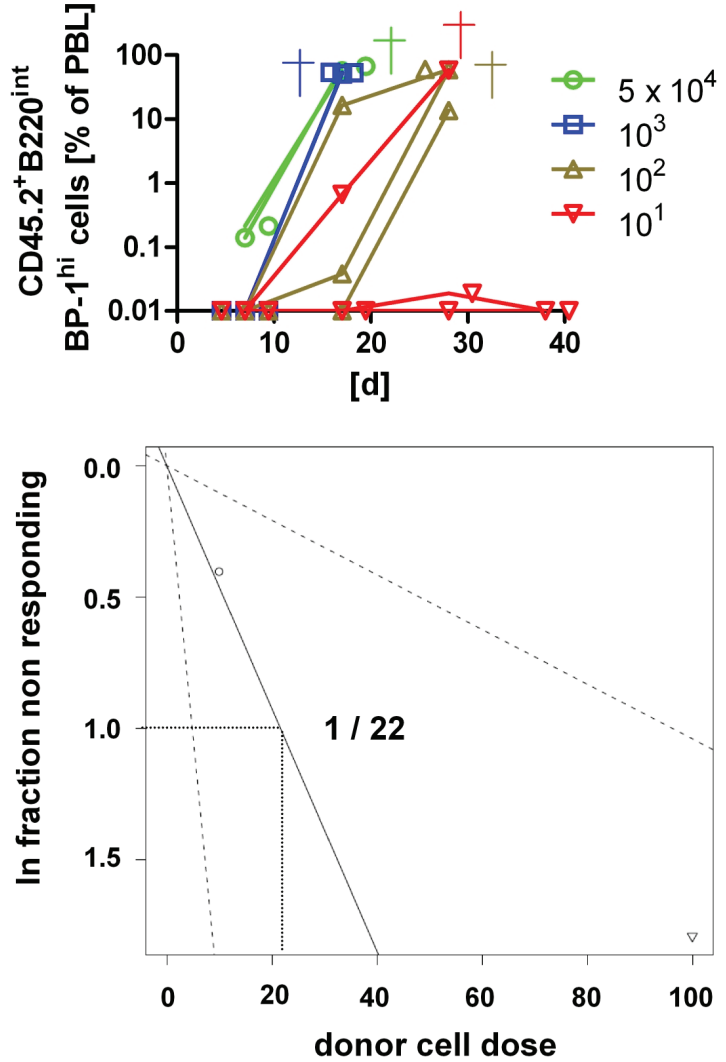

Figure 5 


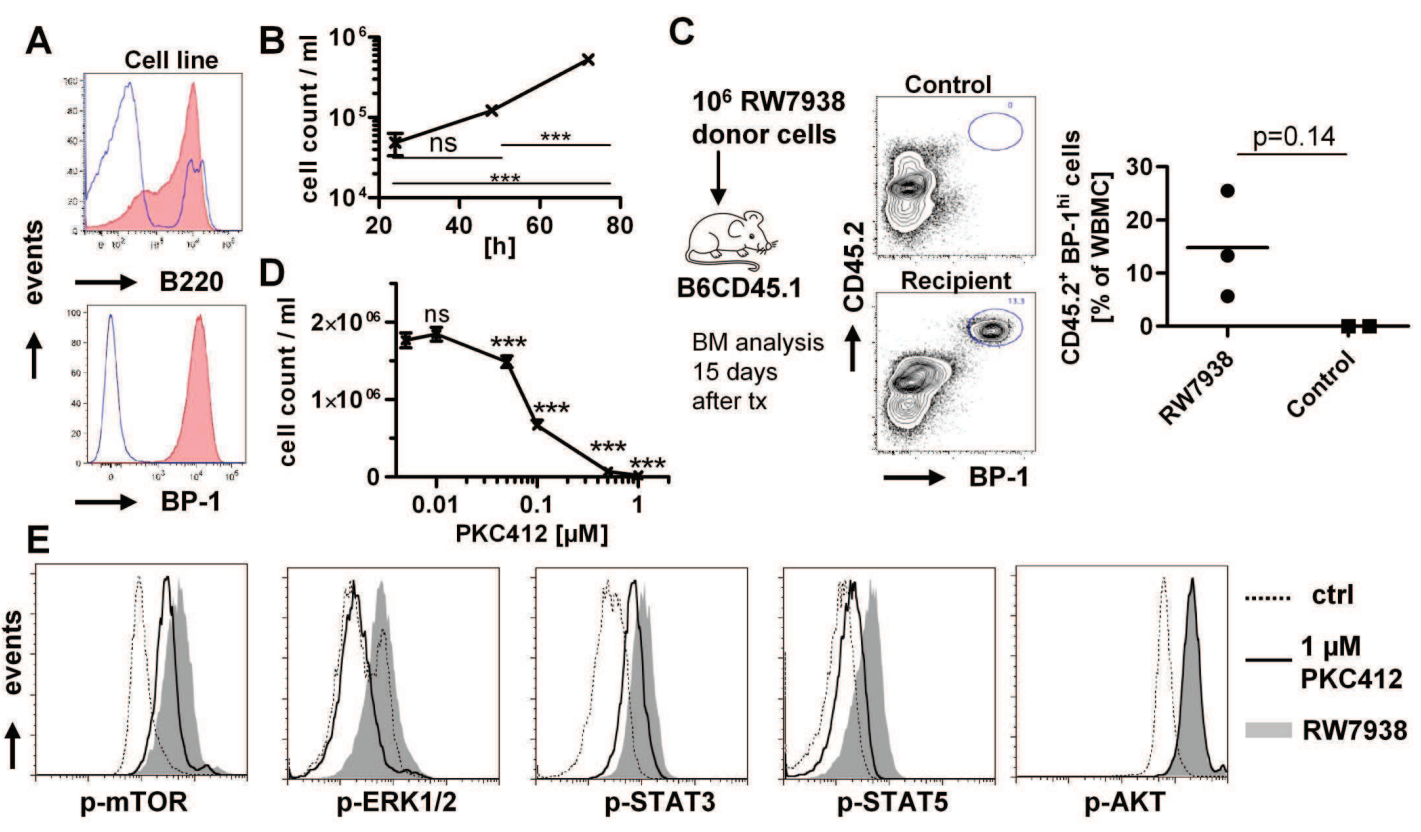

Figure 6 

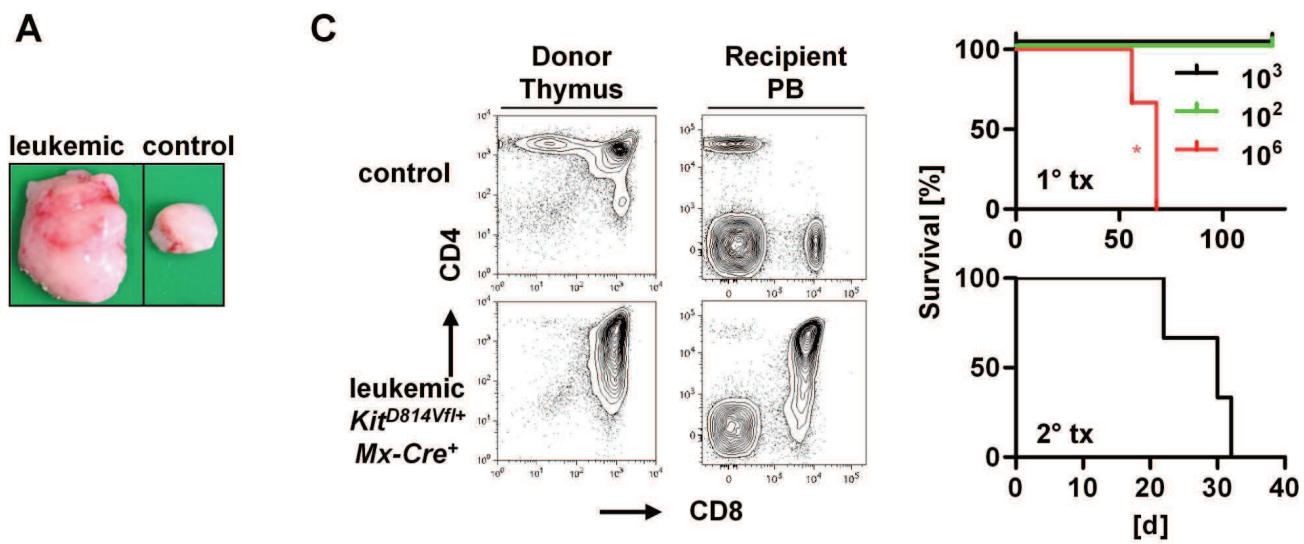

B
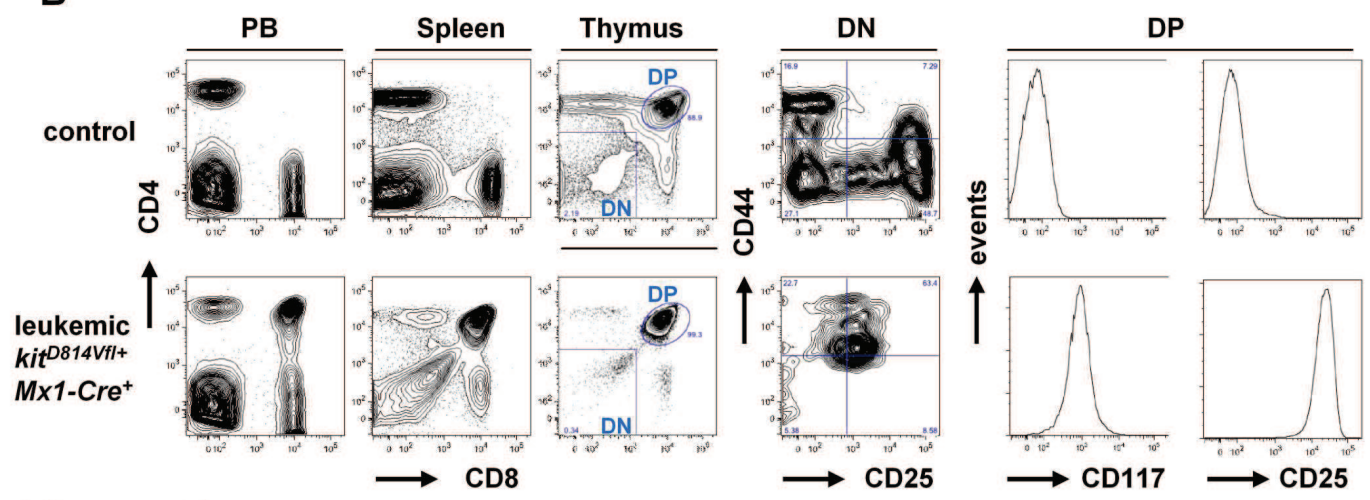

Figure 7 


\section{Supplementary Material}

\section{Constitutive KIT activity triggers B cell acute lymphoblastic leukemia-like disease in mice}

Robin R. Weidemann, Rayk Behrendt, Kristina B. Schoedel, Werner Müller, Axel Roers and Alexander Gerbaulet

\section{Supplementary Table 1}

\begin{tabular}{|c|c|c|}
\hline antigen & clone & manufacturer \\
\hline B220 & RA3-6B2 & $\mathrm{eB} ; \mathrm{BL}$ \\
\hline $\mathrm{BP}-1$ & $6 \mathrm{C} 3$ & $\mathrm{eB}$ \\
\hline CD117 & 2B8 & $\mathrm{eB}$ \\
\hline CD11b & $1 / 70$ & $\mathrm{eB}$ \\
\hline CD127 & A7R34 & eB \\
\hline CD135 & A2F10 & $\mathrm{eB}$ \\
\hline CD19 & eBio1D3 & $\mathrm{eB}$ \\
\hline CD21/35 & eBio4E3 & $\mathrm{eB}$ \\
\hline CD24 & $\mathrm{M} 1 / 69$ & $\mathrm{eB}$ \\
\hline CD24 & $30-\mathrm{F} 1$ & $\mathrm{eB}$ \\
\hline CD25 & PC61.5 & eB \\
\hline CD34 & RAM34 & $e B$ \\
\hline $\mathrm{CD} 4$ & L3T4 & eB \\
\hline CD43 & 1B11 & $\mathrm{BL}$ \\
\hline CD43 & S7 & $\mathrm{BD}$ \\
\hline CD44 & IM7 & $\mathrm{eB}$ \\
\hline CD45.1 & A20 & $\mathrm{eB}$ \\
\hline CD45.2 & 104 & eB \\
\hline CD79b & HM79-12 & $B L$ \\
\hline CD8a & $53-6.7$ & $\mathrm{eB}$ \\
\hline CD93 & AA4.1 & $\mathrm{eB}$ \\
\hline $\lg D$ & $11-26$ & $\mathrm{eB}$ \\
\hline $\lg M$ & $11 / 41$ & $\mathrm{eB}$ \\
\hline phospho-AKT (S473) & SDRNR & eB \\
\hline phospho-ERK1/2 (T202/Y204) & MILAN8R & eB \\
\hline phospho-mTOR (S2448) & MRRBY & $\mathrm{eB}$ \\
\hline phospho-STAT3 (Y705) & LUVNKLA & $\mathrm{eB}$ \\
\hline phospho-STAT5 (Y694) & SRBCZX & $\mathrm{eB}$ \\
\hline Sca1 & D7 & $\mathrm{eB}$ \\
\hline
\end{tabular}

Overview of monoclonal antibodies for flow cytometry.

Manufacturer: eBioscience, eB; Biolegend, BL; BectonDickinson, BD. 

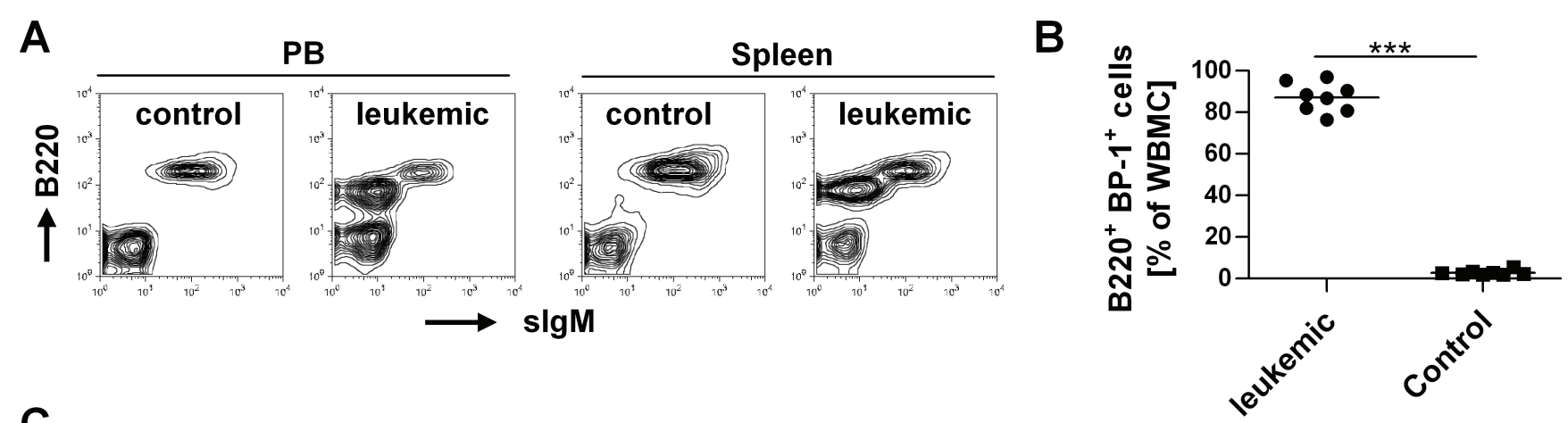

C
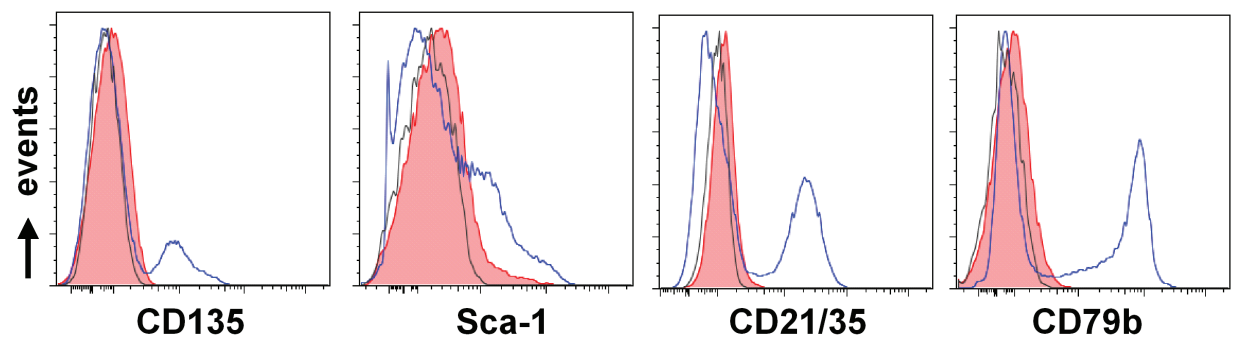

-leukemic

Figure S1

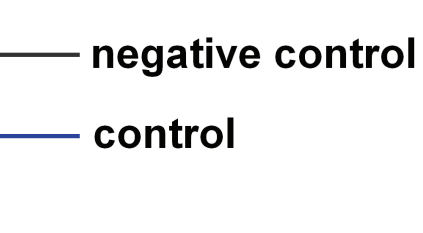


A
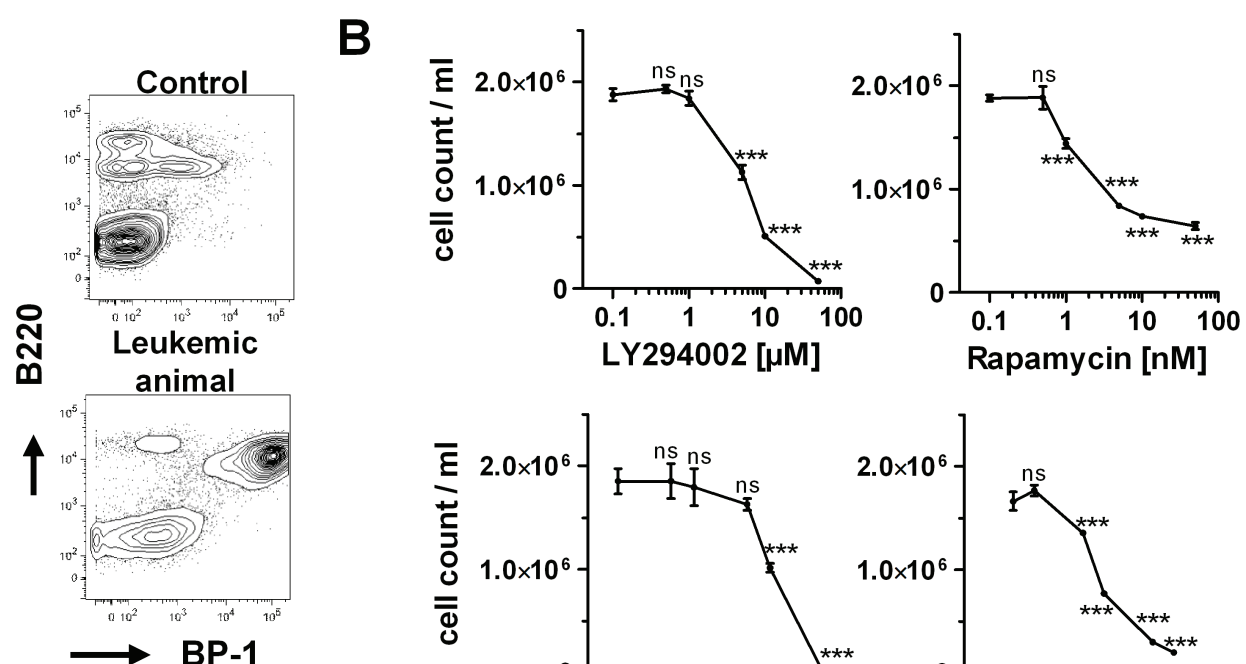

C
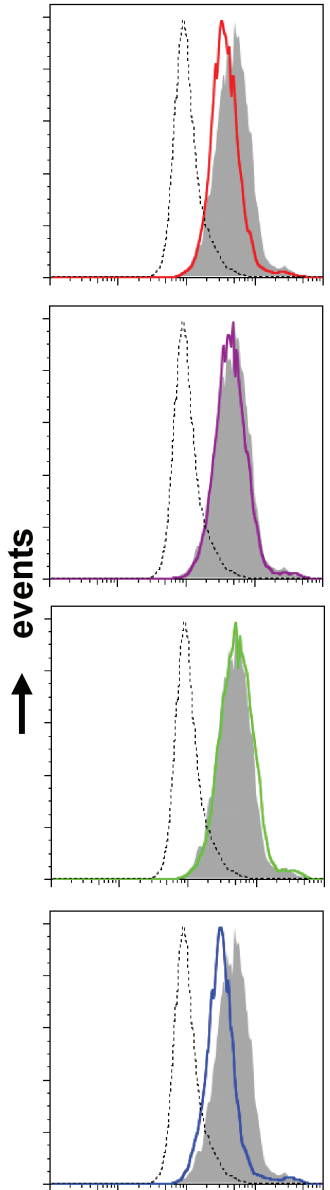

p-mTOR
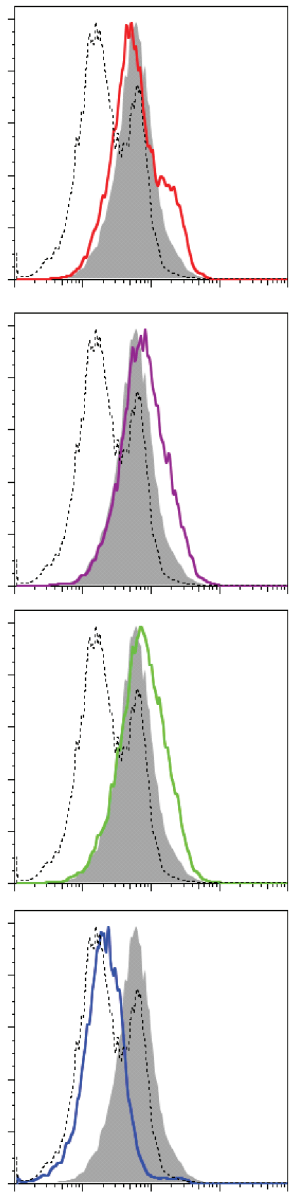

p-ERK1/2
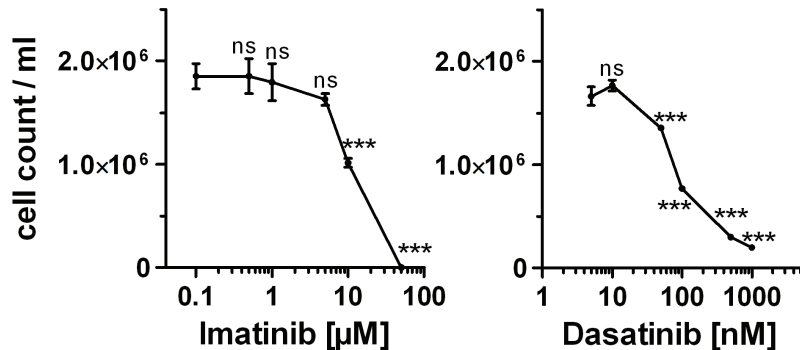
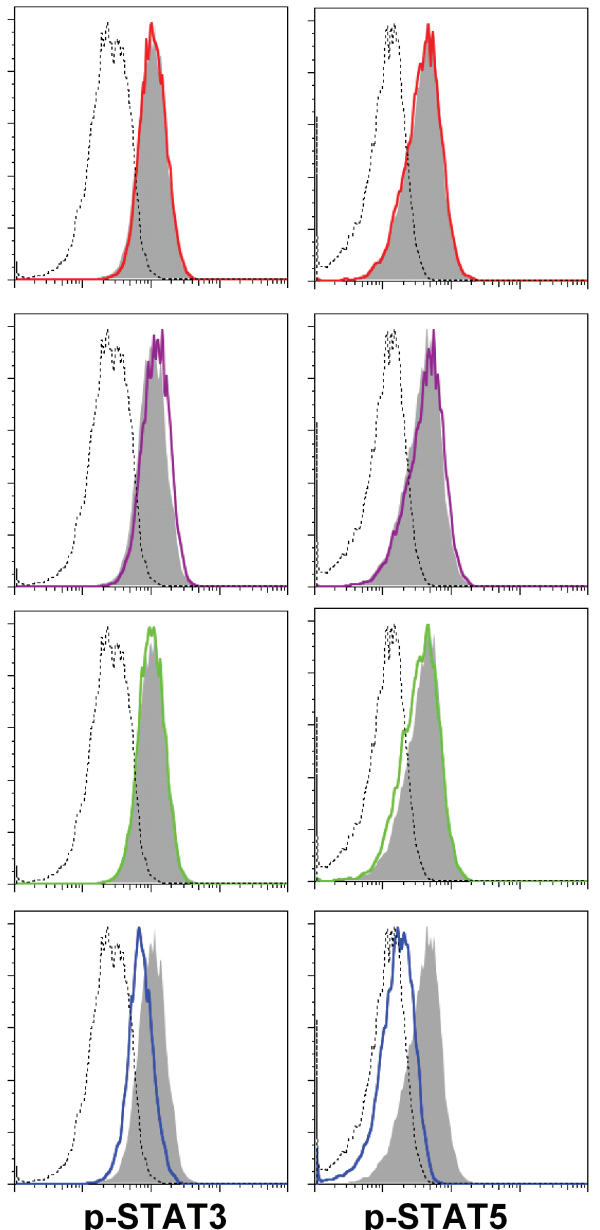

p-STAT5

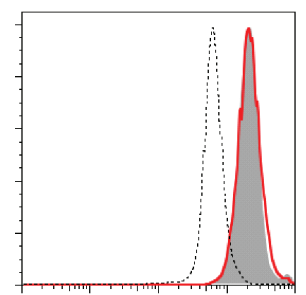

....... ctrl

$50 \mu \mathrm{M}$

LY294002

RW7938

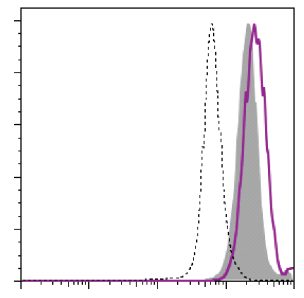

....... ctrl

$10 \mathrm{nM}$

Rapamycin

RW7938

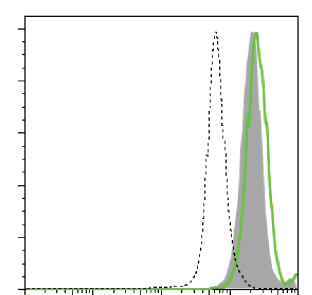

....... ctrl

$10 \mu \mathrm{M}$ Imatinib

RW7938

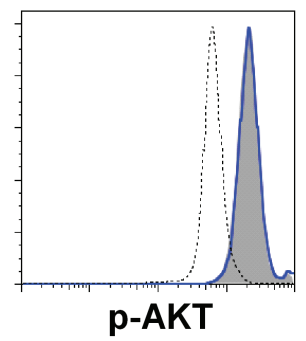

....... ctrl $100 \mathrm{nM}$ Dasatinib

RW7938

Figure S2 
A

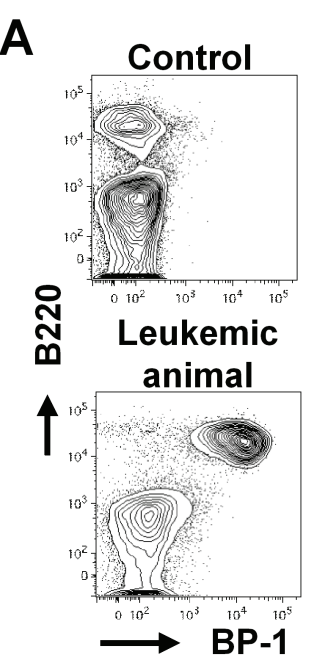

E
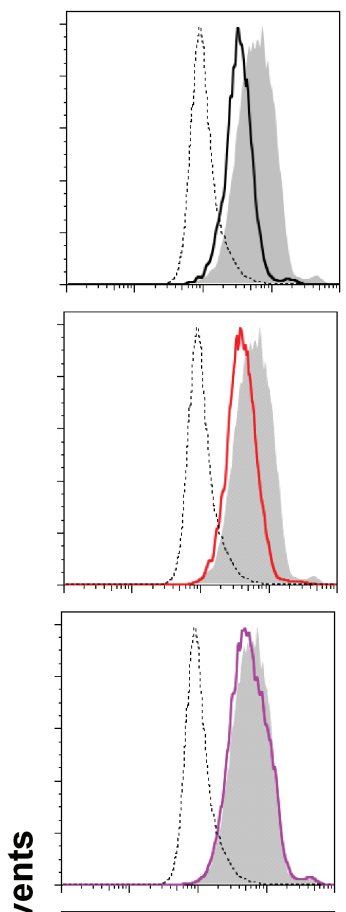

๘
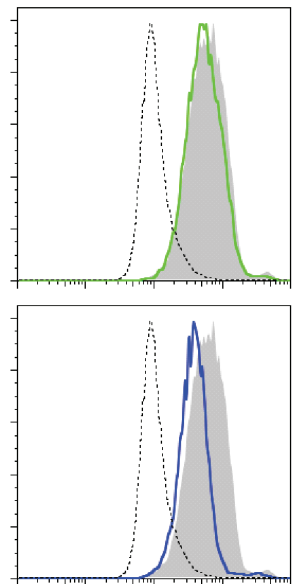

p-mTOR

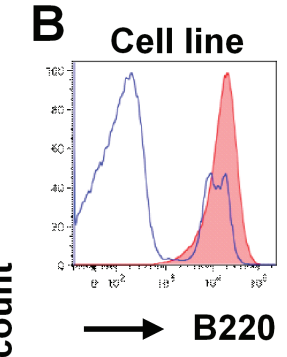

$\uparrow$
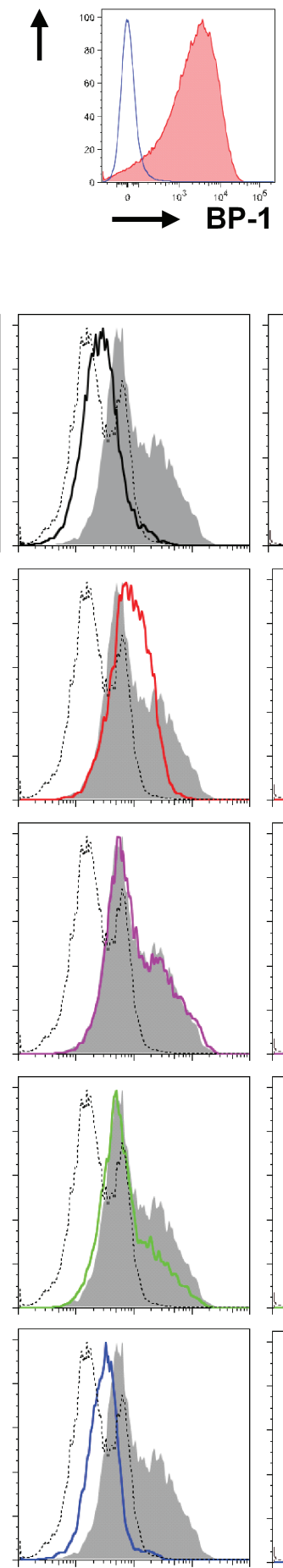

p-ERK1/2

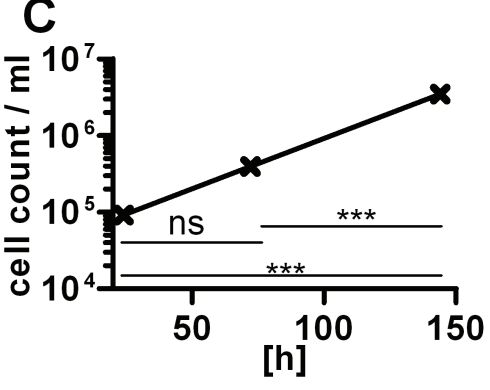

D $\quad 10^{6}$ AG11232

donor cells
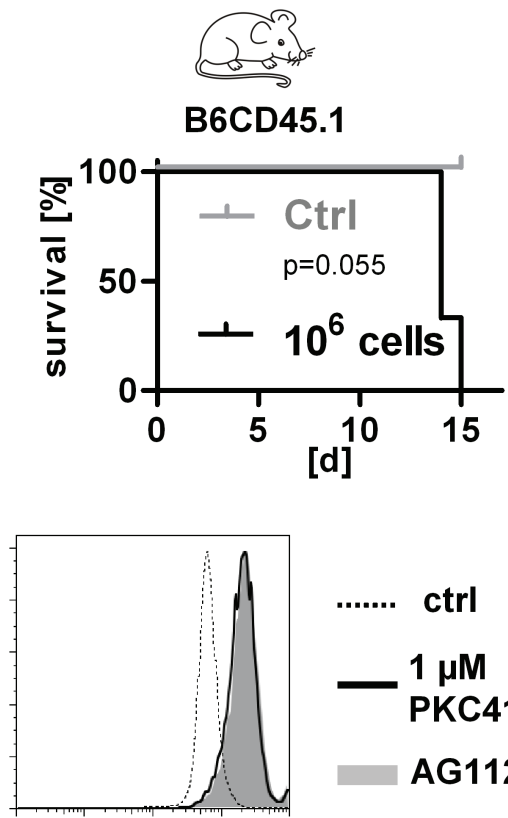

....... ctrl

$1 \mu \mathrm{M}$

PKC412

AG11232

ctrl

$50 \mu \mathrm{M}$

LY294002

AG11232
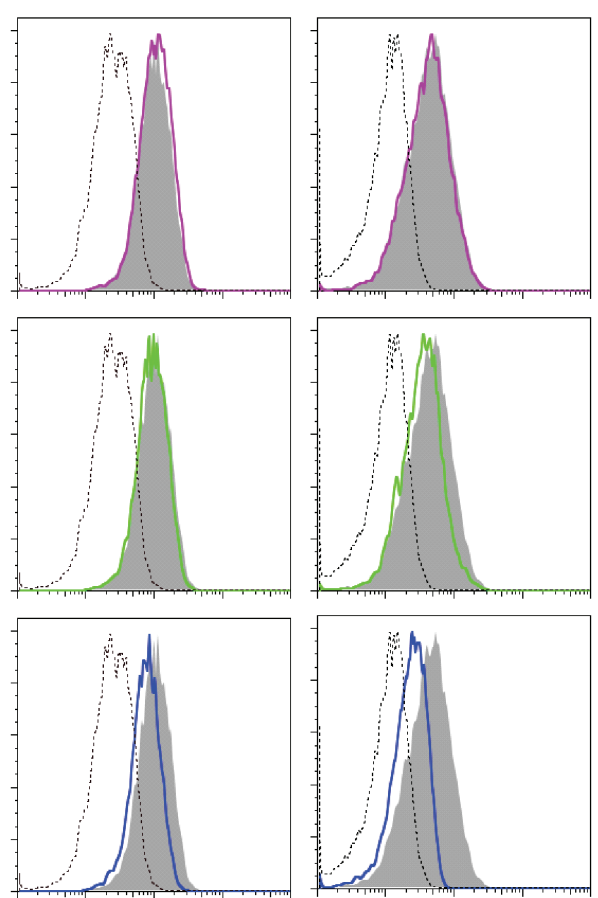

p-STAT3

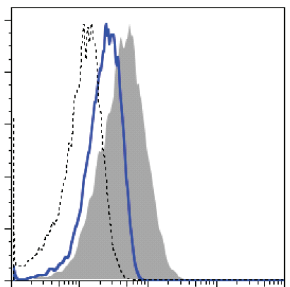

p-STAT5
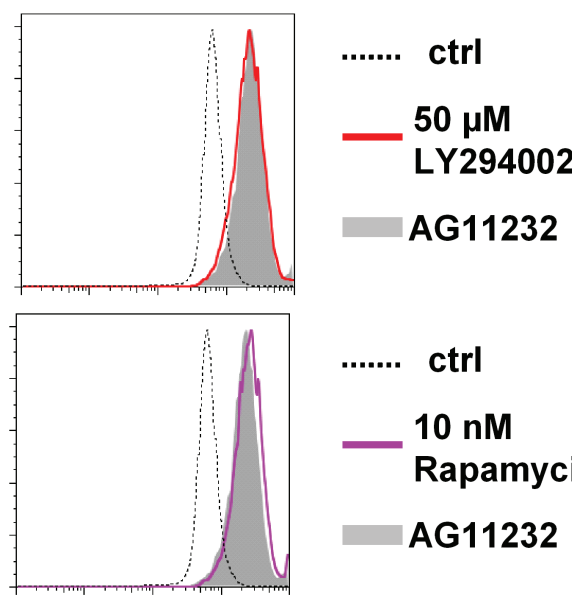

....... ctrl $10 \mathrm{nM}$

Rapamycin

AG11232

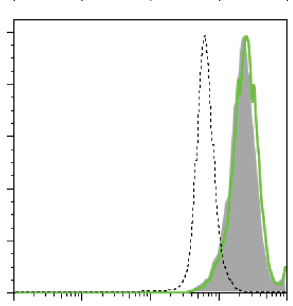

....... ctrl

$10 \mu \mathrm{M}$

Imatinib

AG11232

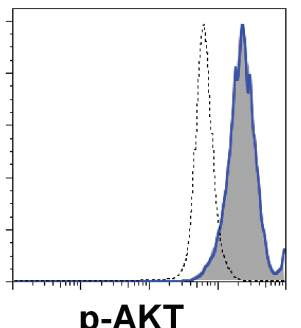

...... ctrl $100 \mathrm{nM}$ Dasatinib

AG11232

F
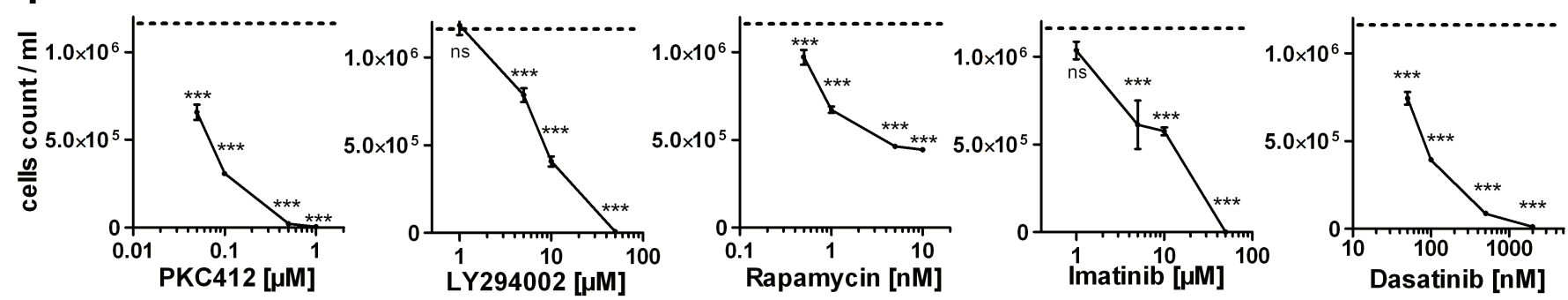

Figure S3 


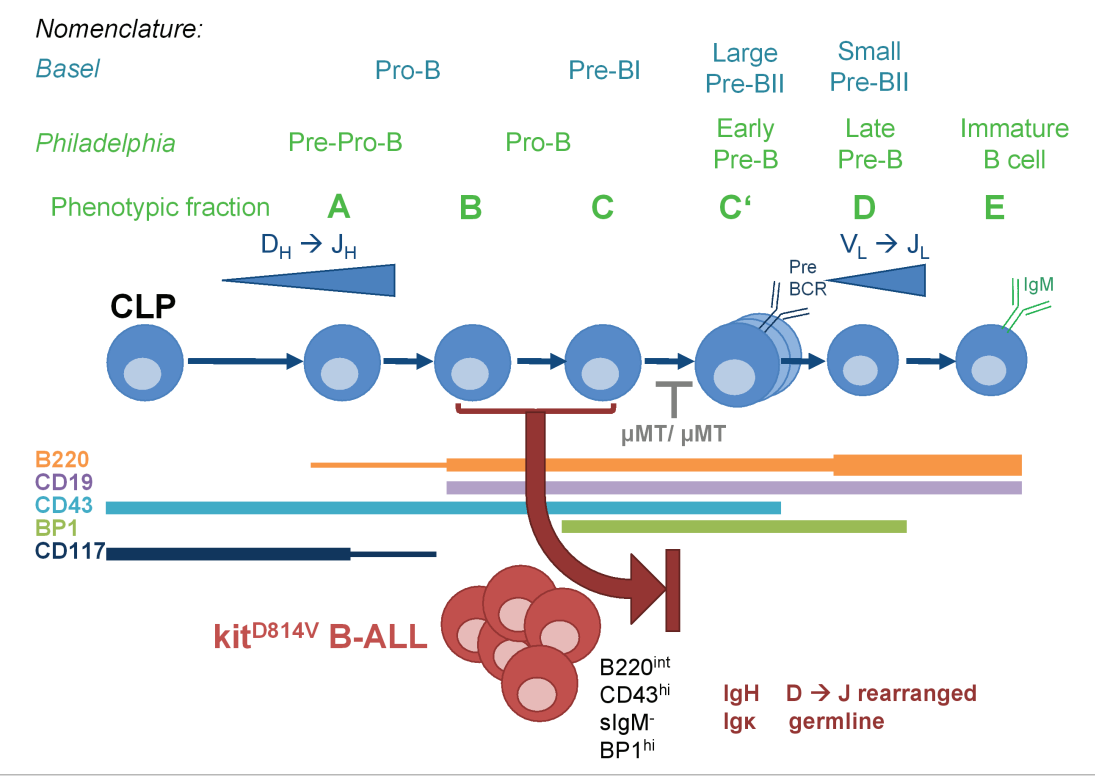

Figure S4 


\section{Supplementary figure legends}

\section{Supplementary figure S1}

\section{Immuno-phenotype of neoplastic B cells from leukemic kit ${ }^{D 814 V}$ transgenic mice} resembles pre-B-I cells.

A) Peripheral blood (PB) and spleen cells of leukemic kit ${ }^{D 14 V \text { flox }} M \times 1$-Cre mice were analyzed for expression of B220 and IgM. B) Frequency of $\mathrm{B} 220^{+} \mathrm{BP}-1^{+}$cells in whole bone marrow cells (WBMC) of leukemic and control animals. C) B220+ WBMCs were analyzed by flow cytometry for expression of CD135, Sca-1, CD21/35 and CD79b (diseased Kit ${ }^{\text {814VFlox+ }^{+}} \mathrm{Mx1- \textrm {Cre } ^ { + }}$ animals, red; healthy $\mathrm{Mx1-Cre^{- }}$ or $\mathrm{Kit}^{\mathrm{D814Vflox}-}$ littermate controls, blue; unstained cells as negative control, grey; 2 animals analyzed, one representative result is shown).

\section{Supplementary Figure S2}

\section{Derivation of precursor B cell line.}

A) BP-1 and B220 expression pattern of BM cells from the diseased animal (lower contour plot, upper plot shows littermate control) that gave rise to the cell line “RW7938”. B) Triplicates of RW7938 cells were cultivated in presence of inhibitory drugs. All compounds were purchased from LClabs, except LY294002 which was obtained from Cell Signaling Technologies (Frankfurt, Germany). Cell counts were determined after $48 \mathrm{~h}$ (means \pm SD are shown, significance between RW7938 cells treated with increasing doses and RW7938 cells treated with the lowest dose of inhibitor was calculated) C) RW7938 cells were cultivated for $2 \mathrm{~h}$ in the presence of indicated compounds (colored histograms) or left untreated (solid histogramm). Cells were fixed and stained with phosphoprotein-specific antibodies and analyzed by flow cytometry. Freshly isolated splenocytes from B6 wt mice (dashed histogram) served as a control for expression of phosphoproteins by primary lymphocytes. 


\section{Supplementary figure S3}

\section{Derivation of a cell line from a diseased $k^{D 814 V}$ CD19-Cre mouse.}

A) BP-1 and B220 expression pattern of BM cells from the diseased animal (lower contour plot) and littermate control (upper dot plot) that gave rise to the cell line "AG11232". B) BM cells were cultivated in RPMI1640/10\% FCS medium for more than 10 passages. FACS analysis revealed a homogenous population of $B 220^{+} \mathrm{BP} 1^{+}$ cells (blue, WBMC of healthy negative control mouse; red, cell line AG11232). C) AG11232 cells were seeded in three replicates and cell numbers were determined at the indicated time points (means \pm SD are shown). D) B6.CD45.1 recipient mice $(n=3)$ rapidly succumbed after i.v. injection of $10^{6}$ AG11232 donor cells. E) AG11232 cells were cultivated for $2 \mathrm{~h}$ in the presence of indicated compounds (colored histograms) or left untreated (solid histogram). Cells were fixed and stained with phosphoprotein-specific antibodies and analyzed by flow cytometry. Freshly isolated splenocytes from B6 wt mice (dashed histogram) served as a control for expression of phosphoproteins by primary lymphocytes. F) Triplicates of AG11232 cells were cultivated in presence of inhibitory drugs. Cell counts were determined after $48 \mathrm{~h}$ (means \pm SD are shown, dotted line represents un-treated AG11232 control cells, significance between treated and un-treated control cells was calculated). 


\section{Supplementary Figure S4}

\section{Overview of $\mathrm{Kit}^{\mathrm{D814V+}}$ B-ALL.}

Graphical abstract shows the Basel (A. Rolink, F. Melchers) and Philadelphia (R. Hardy) nomenclatures of developing B lineage cells. The expression patterns of immuno-phenotypic fractions $A-E$ are indicated in the lower part. Kit ${ }^{\mathrm{D} 14 \mathrm{~V}+} \mathrm{B}-\mathrm{ALL}$ cells develop from (Philadelphia) fraction B or C pro-B cells (which overlap with Basel pre-BI cells), are $\mathrm{D}-\mathrm{J}_{\mathrm{H}}$ rearranged and usually $\mathrm{V}-\mathrm{J}_{\mathrm{K}}$ germline configured. 